\title{
Humic surface waters of frozen peat bogs (permafrost zone) are highly resistant to bio- and photodegradation
}

\author{
Liudmila S. Shirokova ${ }^{1,2}$, Artem V. Chupakov ${ }^{2}$, Svetlana A. Zabelina ${ }^{2}$, Natalia V. Neverova ${ }^{2}$, \\ Dahedrey Payandi-Rolland ${ }^{1}$, Carole Causserand ${ }^{1}$, Jan Karlsson ${ }^{3}$, and Oleg S. Pokrovsky ${ }^{1,4}$ \\ ${ }^{1}$ Geoscience and Environment Toulouse, UMR 5563 CNRS, University of Toulouse, 14 Avenue Edouard Belin, \\ 31400 Toulouse, France \\ ${ }^{2}$ Institute of Ecological Problems of the North, N. Laverov Federal Center for Integrated Arctic Research, \\ Nab Severnoi Dviny 23, Arkhangelsk 163000, Russia \\ ${ }^{3}$ Climate Impacts Research Centre (CIRC), Department of Ecology and Environmental Science, Umeå University, \\ 90187 Umeå, Sweden \\ ${ }^{4}$ BIO-GEO-CLIM Laboratory, Tomsk State University, 35 Lenina Pr., Tomsk 634050, Russia
}

Correspondence: Oleg S. Pokrovsky (oleg.pokrovsky@get.omp.eu)

Received: 27 December 2018 - Discussion started: 14 January 2019

Revised: 27 May 2019 - Accepted: 11 June 2019 - Published: 28 June 2019

\begin{abstract}
In contrast to the large number of studies on humic waters from permafrost-free regions and oligotrophic waters from permafrost-bearing regions, the bio- and photolability of DOM from the humic surface waters of permafrostbearing regions has not been thoroughly evaluated. Following standardized protocol, we measured biodegradation (at low, intermediate and high temperatures) and photodegradation (at one intermediate temperature) of DOM in surface waters along the hydrological continuum (depression $\rightarrow$ stream $\rightarrow$ thermokarst lake $\rightarrow$ Pechora River) within a frozen peatland in European Russia. In all systems, within the experimental resolution of $5 \%$ to $10 \%$, there was no bio- or photodegradation of DOM over a 1-month incubation period. It is possible that the main cause of the lack of degradation is the dominance of allochthonous refractory (soil, peat) DOM in all waters studied. However, all surface waters were supersaturated with $\mathrm{CO}_{2}$. Thus, this study suggests that, rather than bio- and photodegradation of DOM in the water column, other factors such as peat pore-water DOM processing and respiration of sediments are the main drivers of elevated $p \mathrm{CO}_{2}$ and $\mathrm{CO}_{2}$ emission in humic boreal waters of frozen peat bogs.
\end{abstract}

\section{Introduction}

Boreal and subarctic waters contain large amounts of plant, soil and dissolved organic matter of peat origin (Wilkinson et al., 2013; Kaiser et al., 2017), and the proportion of land-derived organic carbon (C) in these waters is likely to increase with ongoing permafrost thaw (Wauthy et al., 2018). Heterotrophic bacteria degrade this DOM (Karlsson et al., 2007; McCallister and del Georgio, 2008), causing net heterotrophic conditions (gross primary productivity $<$ respiration) and $\mathrm{CO}_{2}$ emission to the atmosphere from surface waters (Ask et al., 2012; Lapierre et al., 2013). Between $10 \%$ and $40 \%$ of the dissolved organic carbon (DOC) in the lakes, rivers and soil waters in the boreal zone may be available for bacterial uptake over a time frame of several weeks (Berggren et al., 2010; Roehm et al., 2009). The biodegradability of DOM leached from permafrost and nonpermafrost soils was recently reviewed by Vonk et al. (2015), who concluded that aquatic DOC is more biodegradable in regions with continuous permafrost compared with regions without permafrost. At the same time, among all Arctic rivers, the highest annual $(20 \%)$ and winter (ca. $45 \%$ ) biodegradable DOC (BDOC) was reported for the Ob River, which drains through peatlands with minimal influence from permafrost (Wickland et al., 2012). Furthermore, based on 14 studies of BDOC and their own research, Vonk et al. (2015) demonstrated zero BDOC loss in aquatic systems without 
permafrost, which is contradictory to the general understanding of the biodegradation of aquatic DOM as major driver of $\mathrm{CO}_{2}$ emission in boreal waters. It is also important to note that all of the available biodegradation studies of inland waters in permafrost regions have dealt with either tundra ecosystems, with shallow peat soils overlaying the mineral substrate, or mountain regions, with essentially mineral soil substrates in Alaska or Canada (Holmes et al., 2008; Wickland et al., 2012; Ward et al., 2017) and with the yedoma soils of eastern Siberia (Mann et al., 2014, 2015; Spencer et al., 2015).

Similarly, although the photolysis of DOM in boreal and subarctic aquatic environments contributes to $\mathrm{CO}_{2}$ emission from the inland waters to the atmosphere (Cory et al., 2014), the overwhelming majority of photodegradation studies in the Arctic have been conducted on oligotrophic lake waters and streams draining mineral soils of mountain regions (Ward and Cory, 2016; Cory et al., 2013, 2015). The dominance of photolytic processes in DOM processing in Arctic waters has been reported for North America (Cory et al., 2014; Ward et al., 2017), Canadian surface waters of the temperate zone (Winter et al., 2007; Porcal et al., 2013, 2014, 2015) and small Swedish humic-rich headwater catchments (Köhler et al., 2002). In contrast, several other studies from Scandinavia (Groeneveld et al., 2016; Koehler et al., 2014), Canada (Laurion and Mladenov, 2013; Gareis and Lesack, 2018) and northwestern Russia (Oleinikova et al., 2017; Chupakova et al., 2018) have demonstrated the sizable removal of colored (chromophoric) DOM but a quite small $(\leq 10 \%)$ impact of sunlight irradiation on the bulk DOC concentration in streams, rivers and lakes. Note here that the interaction between bio- and photodegradation is more important than the individual processes, as photooxidation may transform DOM molecular structures into more bioavailable forms (e.g., Cory and Kling, 2018; Sulzberger et al., 2019).

Overall, available data demonstrate that an emerging paradigm regarding the importance of bio- and photodegradation may not be as consistent across the Arctic as previously thought, which outlines a need for further studies of these processes, encompassing a wider range of aquatic settings. The numerous surface waters located within the discontinuous to continuous permafrost zone of northern Eurasia, where most aquatic systems are drained through frozen peat rather than mineral substrates, are poorly studied regarding bio- and photo-degradability of aquatic DOM. However, these regions (northeast European Russia or the Bolshezemelskaya Tundra, the western Siberian lowland, the northern Siberian lowland, Kolyma and the Yana-Indigirka lowland) occupy $>2$ million $\mathrm{km}^{2}$, which is more than $10 \%$ of the total permafrost-affected land area, and they exhibit, on average, a 10 times higher concentration of soil organic carbon - in the form of a 0.5 to $3 \mathrm{~m}$ thick peat layer - than the rest of the circumpolar regions (Tarnocai et al., 2009; Raudina et al., 2018). As a result of the dominance of Histosols, the surface waters draining frozen peatlands are en- riched in DOC compared with other permafrost-affected regions (Manasypov et al., 2014; Pokrovsky et al., 2015) and may provide a disproportionally high contribution to the total DOM bio- and photo-degradability in the Arctic and subarctic regions.

Numerous experiments in permafrost-bearing and permafrost-free aquatic environments, including both organic and mineral soil substrates that are relatively poor in DOC, have demonstrated that the headwater streams and soil leachate contain the most biodegradable and photodegradable DOM (Ilina et al., 2014; Mann et al., 2014, 2015; Larouche et al., 2015; Spencer et al., 2015; Vonk et al., 2015). Photooxidation and biodegradation have also been shown to play an important role in small streams of temperate peatlands in the UK and Scotland (Moody et al., 2013; Pickard et al., 2017; Dean et al., 2019). In the present study, we hypothesized that, given the nutrient-poor nature of Sphagnum peat from Histosols, the bioavailability of essentially recalcitrant DOM in the surface waters of frozen peatlands would be low. Furthermore, we expected a gradient in the degree of the bio- and photolability of DOM from permafrost subsidence, head water streams, thermokarst lakes and large rivers, corresponding to the increase in water residence time (Mann et al., 2012).

To test these hypotheses, we used a recommended standardized protocol for DOM biodegradation (Vonk et al., 2015) and applied it for four main aquatic components of a hydrological continuum: permafrost subsidence $\rightarrow$ small stream $\rightarrow$ large thermokarst lake $\rightarrow$ large river (the Pechora). We chose the largest frozen peatlands in Europe, the Bolshezemelskaya Tundra of northeast European Russia. The Bolshezemelskaya Tundra is represented by flat-mound (palsa) peat bog (discontinuous and continuous permafrost zone) and belongs to the watershed of the largest European permafrost-affected river, the Pechora. The specific goals of this study were (i) to assess the difference in the BDOC and photodegradable (PDOC) fraction of DOM in the surface waters of a frozen peat bog along the hydrological continuum, from permafrost depressions to large rivers, (ii) to quantify the impact of temperature on the biodegradation potential of surface waters from frozen peat bogs and predict the possible impact of warming on DOM biodegradation efficiency, and (iii) to relate the BDOC and PDOC concentrations to the snapshot $\mathrm{CO}_{2}$ concentration and emission.

\section{Study site and methods}

\subsection{Geographical context and hydrological continuum of the Pechora River basin}

The water samples were collected in the middle of July 2017, which is the midsummer period, consistent with the time periods used by other researchers for biodegradation assays. The Bolshezemelskaya Tundra (BZT) peatland (continuous 
to discontinuous permafrost zone) belongs to the Pechora River watershed (Fig. S1 in the Supplement), the largest European Arctic river draining permafrost-bearing terrain (the watershed covers $322000 \mathrm{~km}^{2}$ and has a mean annual discharge of $4140 \mathrm{~m}^{3} \mathrm{~s}^{-1}$ ). The northern part of the Pechora River watershed is covered by permafrost: discontinuous in the eastern part and sporadic to isolated on the western part (Brittain et al., 2009). The BZT is a hilly moraine lowland located between the Pechora and Usa rivers to the west and south and the Polar Urals and the Pai-Khoi ridge to the east. The dominant altitudes are between 100 and $150 \mathrm{~m}$, and are created by hills and moraine ridges, which are composed of sands and silt with boulders. Between the moraines and ridges there are many lakes, mostly of thermokarst origin. The dominant soils are the Histosols of peat bogs and podzolgley soils in the southern forest-tundra zone. The mean annual temperature is $-3.1^{\circ} \mathrm{C}$, and the mean annual precipitation is $503 \mathrm{~mm}$. The dominant vegetation in the tundra zone is mosses, lichens and dwarf shrubs. Over past decades, the lakes of the BZT have exhibited a sizable increase in summer time temperature and $p \mathrm{CO}_{2}$, presumably due to the enhanced bacterial respiration of allochthonous DOM from thawing permafrost (Drake et al., 2019).

We sampled surface waters along the typical hydrological continuum (shown in Fig. S1) that consisted of (1) depressions in the moss and lichen cover of an upland frozen peat bog, filled with water from the thawing of ground ice (permafrost subsidence, $2.5 \mathrm{~m} \times 3 \mathrm{~m}$ size and $0.3 \mathrm{~m}$ depth); (2) a small stream $(\sim 2 \mathrm{~km}$ length) originating from an upland peat bog; (3) a small thermokarst, Lake Isino $\left(S_{\text {area }}=0.005 \mathrm{~km}^{2}\right)$, located within the peat bog; and (4) the mainstream of the Pechora River. A similar hydrological continuum principle was considered in the Kolyma River biodegradation experiments (Mann et al., 2012). The list of the water bodies sampled along with their physical, chemical and microbiological characteristics, and parameters of the $\mathrm{CO}_{2}$ system is presented in Table 1. The surface waters were collected from the shore (depression and stream) or using a PVC boat (Pechora River and Lake Isino). The water samples were placed into $2 \mathrm{~L}$ Milli-Q pre-cleaned PVC jars and kept refrigerated until their arrival to the laboratory, which occurred within $2-3 \mathrm{~h}$ of collection.

\subsection{Experimental setup}

\subsubsection{Biodegradation}

For biodegradation assays we followed the standardized protocol for assessing biodegradable DOC of Arctic waters (Vonk et al., 2015). To facilitate the implementation of recommended protocol, we used exactly the same filter towers, inline filter holders and vacuum devices as those depicted in Vonk et al. (2015). Initial samples were filtered through pre-combusted $\left(4.5 \mathrm{~h}\right.$ at $\left.450^{\circ} \mathrm{C}\right)$ Whatman GF/F filters of a $0.7 \mu \mathrm{m}$ nominal pore size. All of the manipulations were performed in laminar hood box (class A100) under sterile environmental conditions: the working space was sterilized using an ultraviolet (UV) light before preparation. Triplicate $30 \mathrm{~mL}$ aliquots of $0.7 \mu \mathrm{m}$ filtered water were placed into pre-combusted $\left(4.5 \mathrm{~h}\right.$ at $\left.450^{\circ} \mathrm{C}\right)$ dark borosilicate glass bottles with a volume of $40 \mathrm{~mL}$ without nutrient amendment, were wrapped in aluminum foil to prevent any photolysis and were stored at $23 \pm 1{ }^{\circ} \mathrm{C}$ in the dark. The bottles were closed with sterilized PVC caps. As recommended, the caps were left loose and the bottles were shaken manually once a day; the liquid touching the cap during shaking was avoided. The incubated samples were refiltered through pre-combusted $0.7 \mu \mathrm{m} \mathrm{GF} / \mathrm{F}$ filters using sterilized dismountable Sartorius $25 \mathrm{~mm}$ filter holder and a cleaned sterile syringe after $0,2,7,14$ and $28 \mathrm{~d}$ of exposure. Filtered samples were acidified with $30 \mu \mathrm{L}$ of concentrated $(8.1 \mathrm{M})$ doubledistilled $\mathrm{HCl}$, tightly capped and stored in the refrigerator before DOC analyses. The non-acidified portion of the filtrate was used for $\mathrm{pH}$, specific conductivity, DIC (dissolved organic carbon), and $\mathrm{UV}_{254 \mathrm{~nm}}$ and optical spectra measurement. Control runs were $0.22 \mu \mathrm{m}$ sterile-filtered water which was incubated in parallel to the experiments and refiltered through $0.7 \mu \mathrm{m} \mathrm{GF/F}$ filters on the day of sampling.

In addition to this "classic" protocol, we used an alternative biodegradation experiment procedure to test the maximum possible DOM removal by bacteria. For this, we replaced the initial $0.7 \mu \mathrm{m} \mathrm{GF} / \mathrm{F}$ filtration with $3 \mu \mathrm{m}$ filtration through sterilized nylon Sartorius membranes in order to increase the amount of bacterial cells capable to degrade DOM during incubation. The reason for this was that conventional $0.7 \mu \mathrm{m}(\mathrm{GF} / \mathrm{F})$ filtration might remove too many microbial cells (Dean et al., 2018). In addition, re-filtration through the same filter pore size as that recommended in the classic protocol $(0.7 \mu \mathrm{m})$ may not necessarily remove the newly formed microbial biomass, as the cell size of bacteria grown during incubation may not exceed $0.7 \mu \mathrm{m}$. In this regard, initial $3 \mu \mathrm{m}$ filtration is equivalent to the $100 \%$ inoculum used by Vonk et al. (2015) and can be considered to be the maximal enhancement of DOM biodegradation without the addition of nutrients. Furthermore, instead of $0.7 \mu \mathrm{m}$ re-filtration for sampling, we employed a $0.22 \mu \mathrm{m}$ filter pore size for DOC sampling during incubation. This allowed for the removal of all particulate organic carbon formed via microbial metabolism, as well as some newly grown microbial cells; therefore, this should enhance the degree of biodegradation, calculated as the difference between the initial $3 \mu \mathrm{m}$ filtration and the $0.22 \mu \mathrm{m}$ filtration on the date of sampling. The control runs were filtered through sterile $0.22 \mu \mathrm{m}$ filters and incubated parallel to the experiments, following the standard approach for control abiotic experiments in incubation experiments (Köhler et al., 2002). They were refiltered through $0.22 \mu \mathrm{m}$ membrane on the day of experimental sampling. To ensure the lack of DOC release from the sterilized nylon membrane, we ran blank (Milli-Q) filtration through both $0.7 \mu \mathrm{m} \mathrm{GF} / \mathrm{F}$ and $0.22 \mu \mathrm{m}$ nylon filters; in both cases the 
Table 1. Landscape setting, hydrochemical characteristics and $\mathrm{CO}_{2}$ concentration, and emission flux of the waters studied. "S.C." refers to specific conductivity, and "TBC" is total bacteria count (using the DAPI fluorescence method).

\begin{tabular}{|c|c|c|c|c|}
\hline Sample & BZ-2-17 & BZ-24-17 & $\mathrm{BZ}-12$ & P5 \\
\hline GPS coordinates & $\begin{array}{l}67^{\circ} 36^{\prime} 48,8^{\prime \prime} \mathrm{N} \\
53^{\circ} 54^{\prime} 29.8^{\prime \prime} \mathrm{E}\end{array}$ & $\begin{array}{l}67^{\circ} 36.53^{\prime} \mathrm{N} \\
53^{\circ} 50.26^{\prime} \mathrm{E}\end{array}$ & $\begin{array}{l}67^{\circ} 36^{\prime} 47,7^{\prime \prime} \mathrm{N} \\
53^{\circ} 54^{\prime} 38.5^{\prime \prime} \mathrm{E}\end{array}$ & $\begin{array}{l}67^{\circ} 40^{\prime} 09,4^{\prime \prime} \\
52^{\circ} 39^{\prime} 30.8^{\prime \prime}\end{array}$ \\
\hline Description & $\begin{array}{l}\text { Depression in peat bog, } \\
S_{\text {area }}=7.5 \mathrm{~m}^{2}\end{array}$ & $\begin{array}{l}\text { Stream in frozen peatland, } \\
S_{\text {watershed }}=7.5 \mathrm{~km}^{2}\end{array}$ & $\begin{array}{l}\text { Thermokarst lake (Lake Isino), } \\
S_{\text {area }}=0.005 \mathrm{~km}^{2}\end{array}$ & $\begin{array}{l}\text { Pechora River, } \\
S_{\text {watershed }}=322000 \mathrm{~km}^{2}\end{array}$ \\
\hline$T\left({ }^{\circ} \mathrm{C}\right)$ & 24 & 25 & 24.1 & 20 \\
\hline $\mathrm{pH}$ & 3.85 & 6.52 & 5.30 & 6.92 \\
\hline S.C. $\left(\mu \mathrm{S} \mathrm{cm}^{-1}\right)$ & 59.2 & 31.5 & 12.9 & 65.1 \\
\hline $\operatorname{DOC}\left(\mathrm{mg} \mathrm{L}^{-1}\right)$ & 43.9 & 16.6 & 15.6 & 8.20 \\
\hline $\mathrm{DIC}\left(\mathrm{mg} \mathrm{L}^{-1}\right)$ & 0.992 & 2.52 & 0.808 & 6.11 \\
\hline $\mathrm{SUVA}_{254}$ & 4.08 & 3.32 & 4.10 & 3.82 \\
\hline $\mathrm{P}^{-} \mathrm{PO}_{4}\left(\mu \mathrm{g} \mathrm{L}^{-1}\right)$ & 2.3 & 9.8 & 4.4 & 26.7 \\
\hline$P_{\text {total }}\left(\mu \mathrm{g} \mathrm{L}^{-1}\right)$ & 14.6 & N.D. & 7.3 & 37.5 \\
\hline $\mathrm{N}-\mathrm{NO}_{2}\left(\mu \mathrm{g} \mathrm{L}^{-1}\right)$ & 14.6 & 5.0 & 3.6 & 1.67 \\
\hline $\mathrm{N}-\mathrm{NO}_{3}\left(\mu \mathrm{g} \mathrm{L}^{-1}\right)$ & 14.6 & N.D. & 76.6 & 111 \\
\hline $\mathrm{N}-\mathrm{NH}_{4}\left(\mu \mathrm{g} \mathrm{L}^{-1}\right)$ & 13 & 152 & 117 & 36.5 \\
\hline $\mathrm{N}_{\text {total }}\left(\mu \mathrm{g} \mathrm{L}^{-1}\right)$ & 228 & N.D. & 200 & 438 \\
\hline $\mathrm{Si}\left(\mu \mathrm{g} \mathrm{L}^{-1}\right)$ & 22 & 392 & 100 & 2690 \\
\hline TBC $\times 10^{6}\left(\right.$ cell mL $\left.\mathrm{mL}^{-1}\right)$ & 0.81 & 5.72 & 5.36 & 3.51 \\
\hline$p \mathrm{CO}_{2}(\mathrm{ppm})$ & 440 & 2370 & 1200 & 1860 (night), 780 (day) \\
\hline $\mathrm{CO}_{2}$ flux $\left(\mathrm{mmol} \mathrm{m}^{-2} \mathrm{~d}^{-1}\right)$ & 34 & $30-300^{\mathrm{a}}$ & 74 & $100-130^{\mathrm{b}}$ \\
\hline
\end{tabular}

${ }^{a}$ By analogy with small streams of the western Siberian peatlands in the discontinuous permafrost zone, which are located in a similar environmental context;

$\mathrm{b}$ by analogy with the Taz and Pur rivers of the western Siberian peatlands (Serikova et al., 2018).

DOC blank was below $0.1-0.2 \mathrm{mg} \mathrm{L}^{-1}$, which is less than $1 \%$ of the DOC concentration in our samples. The glass bottles were incubated in triplicates at $4 \pm 2,22 \pm 1$ and $37 \pm 3{ }^{\circ} \mathrm{C}$ using a refrigerator and incubators and agitated manually at least once a day over the 4-week exposure period.

\subsubsection{Photodegradation}

For photodegradation incubations, water samples of all sites except the river were collected in polypropylene jars and sterile filtered $(0.22 \mu \mathrm{m}$ Nalgene Rapid-Flow sterile systems) within $2 \mathrm{~h}$ of sampling before they were refrigerated. The filtrates were transferred under a laminar hood box into sterilized, acid-washed quartz tubes $(150 \mathrm{~mL}$ volume, $20 \%$ air headspace) and placed at a $3 \pm 2 \mathrm{~cm}$ depth into an outdoor pool that was filled with river water with a light transparency similar to that of the Pechora River (1.5-2.0 m Secchi depth). In situ measurements of sunlight intensity were conducted using a submersible sunlight sensor. The outdoor pools were placed in an unshaded area at a latitude similar to that of the sampling sites. Slight wind movement and regular manual shaking allowed for sufficient mixing of the interior of the reactors during exposure. All of the experiments were run in triplicates. The water temperature was $19 \pm 3{ }^{\circ} \mathrm{C}$ over the $28 \mathrm{~d}$ exposure period (17 July-14 August 2017), with an average magnitude of diurnal water temperature variation of $6^{\circ} \mathrm{C}$ (recorded every $3 \mathrm{~h}$ using EBRO EBI 20 series loggers). The day light intensity was typically between 5000 and 20000 lux (10000 lux or $14 \pm 5 \mathrm{~W} \mathrm{~m}^{-2}$ on average), which is within the range of solar radiation at the latitude of the polar circle during this period of the year. Overall, we followed the conventional methodology for photodegradation, which is the exposure of $0.2 \mu \mathrm{m}$ sterile filtered samples in quartz reactors in an outdoor pool (Vähätalo et al., 2003; Chupakova et al., 2018; Gareis and Lesack, 2018), solar simulator (Lou and Xie, 2006; Amado et al., 2014) or directly in lake water (Laurion and Mladenov, 2013; Groeneveld et al., 2016). Note that $0.22 \mu \mathrm{m}$ sterile filtration is the only way to conduct photodegradation experiments, given that the autoclave sterilization of DOM-rich natural water would coagulate humic material and is, therefore, not suitable (Andersson et al., 2018). We chose a 4-week exposure time for consistency with the biodegradation experiments described above and following previous studies on photodegradation under sunlight, which is typically from 15 to $70 \mathrm{~d}$ (Moran et al., 2000; Vähätalo and Wetzel, 2004; Mostofa et al., 2007; Helms et al., 2008; Chupakova et al., 2018). Dark control experiments were conducted in duplicates, using sterilized glass tubes filled with sterile $0.22 \mu \mathrm{m}$ filtered water, wrapped in aluminum foil and placed in the same outdoor pool as the experiments. The headspace (approx. $20 \%$ of total reaction volume) was similar in the experimental and control reactors. The individual reactors were sterile sampled at the beginning of the experiment and on days 2, 7, 14, 21 and 28 of exposure. Each sampling sacrificed the entire reactor. The Milli-Q blanks were collected and processed to monitor for any potential sample contamination introduced by our filtration, incubation, han- 
dling and sampling procedures. The organic carbon blanks of filtrates never exceeded $0.2 \mathrm{mg} \mathrm{L}^{-1}$.

\subsection{Analyses and treatment}

The temperature, $\mathrm{pH}, \mathrm{O}_{2}$ and specific conductivity of surface waters were measured in the field, as described previously (Shirokova et al., 2013b). The dissolved $\mathrm{CO}_{2}$ concentration was measured using a submersible Vaisala CARBOCAP ${ }^{\circledR}$ GM70 hand-held carbon dioxide meter with GMP222 probes (accuracy 1.5\%), see Serikova et al. (2018, 2019) for methodological details. The diffusional $\mathrm{CO}_{2}$ flux was calculated using a wind-based model (Cole and Caraco, 1998) with $k_{600}=2.07+0.215 \times u_{10}^{1.7}$, where $u_{10}$ is the wind speed at a height of $10 \mathrm{~m}$. In the filtrates, we measured optical density at $254 \mathrm{~nm}$ and at selected wavelengths (365, 436, 465 and $665 \mathrm{~nm}$ ) of the visible spectrum. The specific UV absorbency $\left(\mathrm{SUVA}_{254}, \mathrm{~L} \mathrm{mg}^{-1} \mathrm{~m}^{-1}\right.$ ) and E4 : E6 ratios were used as a proxies for aromatic carbon, molecular weight and DOM source (Weishaar et al., 2003; Peacock et al., 2014; Ilina et al., 2014).

The DOC and DIC were analyzed by high-temperature catalytic oxidation using a TOC-VCSN instrument (Shimadzu $^{\circledR}$; uncertainty $\pm 2 \%, \quad 0.1 \mathrm{mg} \mathrm{L}^{-1}$ detection limit). The DIC was measured after sample acidification with $\mathrm{HCl}$, and the DOC was analyzed in acidified samples after sparging it with C-free air for $3 \mathrm{~min}$ at $100 \mathrm{~mL} \mathrm{~min}^{-1}$ as non-purgeable organic carbon (NPOC). Selected quartz reactors in photodegradation experiments were utilized to measure dissolved $\mathrm{O}_{2}$ using an Oxi $197 \mathrm{i}$ oximeter with a CellOx ${ }^{\circledR} 325$ galvanic submersible sensor (WTW, Germany; $\pm 0.5 \%$ uncertainty). For this, the $\mathrm{O}_{2}$ galvanic sensor was introduced into the quartz tube immediately after the reactor was opened and was allowed to equilibrate for 5-10 min; during this procedure, the open end of the tube was protected from exchange with atmospheric oxygen by wrapping it in aluminum foil. All filtered samples collected from the photodegradation experiments were acidified with ultrapure nitric acid and analyzed for major and trace elements following procedures employed by GET (Géosciences Environnement Toulouse) for the analysis of boreal humic waters (Oleinikova et al., 2017, 2018).

To account for possible microbial development in biodegradation experiments, we performed an oligotrophic and eutrophic bacteria count during the course of incubation, following the standard methodology used in biodegradation experiments of peat waters (Stutter et al., 2013), as described previously (Shirokova et al., 2017b; Chupakova et al., 2018). In addition, we measured the total bacterial number and quantified the dominant cell size morphology using the DAPI fluorescence method (Porter and Feig, 1980). Control experiments did not demonstrate the presence of any countable cells in the observation fields.
The bio- and photodegradable DOC (BDOC and PDOC, respectively) were calculated in percent loss relative to the control at each sampling time point $t(0,2,7,14$ and $28 \mathrm{~d})$ according to the following equation:

$\operatorname{BDOC}(\%)_{t}=100 \% \times\left(\mathrm{DOC}_{t, \text { control }}-\mathrm{DOC}_{t}\right) / \mathrm{DOC}_{t, \text { control }}$

Alternatively, the BDOC and PDOC were calculated in percent loss at time point $t$ relative to the initial concentration of DOC $\left(\right.$ DOC $\left._{t=0}\right)$ following Vonk et al. (2015):

$\operatorname{BDOC}(\%)_{t}=100 \% \times\left(\mathrm{DOC}_{t=0}-\mathrm{DOC}_{t}\right) / \mathrm{DOC}_{t=0}$.

For most treatments and waters sampled, the difference between the percent loss calculated by the two methods of bio/photodegradable DOC concentration was statistically negligible. To assess the variability of the results, shown as vertical uncertainties in the graphs, we used the percentage ratio of the standard deviation of $n$ replicates on the $i$ th day of exposure to the initial DOC concentration using the following equation:

$$
\begin{aligned}
\mathrm{SD}_{i} & =\sqrt{\left.\frac{+\left(\mathrm{BDOC}_{i}^{1}-\mathrm{BDOC}_{i}^{\text {mean }}\right)^{2}}{n}-\mathrm{BDOC}_{i}^{\text {mean }}\right)^{2}+\ldots\left(\mathrm{BDOC}_{i}^{n}-\mathrm{BDOC}_{i}^{\text {mean }}\right)^{2}} \\
\% \mathrm{SD}_{i}= & \frac{\mathrm{SD}_{i}}{\mathrm{DOC}_{0}} \cdot 100 .
\end{aligned}
$$

(The results are presented as $\% \mathrm{BOD}_{i} \pm \mathrm{SD}_{i}$.)

To assess the uncertainties during photodegradation experiments, we used the percentage of the standard deviation on $n$ replicates on the $i$ th day of exposure to the DOC concentration in the dark (control) reactors as follows:

$$
\begin{aligned}
& \mathrm{PDOC}_{i}^{n}=\mathrm{DOC}_{i}^{\text {blank }}-\mathrm{DOC}_{i}^{n} \\
& \mathrm{PDOC}_{i}^{\text {mean }}=\frac{\mathrm{PDOC}_{i}^{1}+\mathrm{PDOC}_{i}^{2}+\ldots \mathrm{PDOC}_{i}^{n}}{n} \\
& \mathrm{PDDOC}_{i}=\frac{\mathrm{PDOC}_{i}^{\text {mean }}}{\mathrm{DOC}_{i}^{\text {blank }} \cdot 100} \\
& \mathrm{SD}_{i}=\sqrt{\frac{+\left(\mathrm{PDOC}_{i}^{2}-\mathrm{PDOC}_{i}^{\text {mean }}\right)^{2}+\ldots\left(\mathrm{PDOC}_{i}^{n}-\mathrm{PDOC}_{i}^{\text {mean }}\right)^{2}}{n}} \\
& \%_{\mathrm{SD}_{i}}=\frac{\mathrm{SD}_{i}}{\mathrm{DOC}_{i}^{\text {blank }}} \cdot 100 .
\end{aligned}
$$

(The results are presented as $\% \mathrm{PDOC}_{i} \pm \mathrm{SD}_{i}$.)

Note that if negative values were provided by Eq. (2), the BDOC was taken as $0 \%$ following the conventional practice in biodegradation experiments (Vonk et al., 2015). The uncertainties of the BDOC percentages were between $\pm 5 \%$ and $\pm 10 \%$ for experiments, at 4,23 and $37^{\circ} \mathrm{C}$ using the modified (3 and $0.22 \mu \mathrm{m}$ filtration) protocol. Using the "classic" protocol $(0.7 \mu \mathrm{m} \mathrm{GF} / \mathrm{F}$ filtration) the uncertainties were as high as $10 \%-15 \%$ at the end of experiment. We believe that such 
high uncertainties are linked to a high initial DOC concentration, triplicate measurements and simultaneous monitoring of the experimental and control runs.

Statistical treatment included the least squares method and the Pearson correlation method, as the data were normally distributed. The ANOVA method was used to test the differences in the average DOC concentration versus time in incubation experiments and in the controls and to assess the difference between the light experiments and the dark control for photodegradation experiments. All calculations were performed in STATISTICA version 10 (at $p=0.05$; StatSoft Inc., Tulsa).

\section{Results}

\subsection{Assessment of biodegradable DOC}

The waters of the hydrological continuum within the Pechora River basin are highly diverse (Table 1 ), with $\mathrm{pH}$ values ranging from 3.8 (frozen peat depression) to 6.9 (Pechora River). The soluble salt concentrations were low, as the specific conductivity ranged from $20 \pm 10 \mu \mathrm{S} \mathrm{cm}^{-1}$ (stream and thermokarst lake) to $\sim 60 \mu \mathrm{S} \mathrm{cm}^{-1}$ (in the peat bog depression and the Pechora River). The DOC concentration decreased from $44 \mathrm{mg} \mathrm{L}^{-1}$ in frozen peat depressions to $8 \mathrm{mg} \mathrm{L}^{-1}$ in the Pechora River following the order of water residence time (flow direction)" depression $\gg$ stream $\geq$ thermokarst lake $>$ Pechora River. The DOC concentration was generally similar (within $\pm 2 \%$ ) between samples that had initially undergone respective $3,0.7$ and $0.22 \mu \mathrm{m}$ pore size filtration, which was in agreement with former size fractionation measurements in Arctic and subarctic systems (Vasyukova et al., 2010; Pokrovsky et al., 2012, 2016). All sampled surface waters exhibited $\mathrm{CO}_{2}$ supersaturation with respect to the atmosphere (from 440 to $2400 \mathrm{ppm}$ ) and a net $\mathrm{CO}_{2}$ emission (diffusion) flux ranging from 30 to $300 \mathrm{mmol} \mathrm{CO}_{2} \mathrm{~m}^{-2} \mathrm{~d}^{-1}$ (Table 1).

In both biodegradation experiment protocols, two major features were noted: (1) the concentrations of $0.7 \mu \mathrm{m}$ and $0.22 \mu \mathrm{m}$ filtered DOC did not decrease during the exposure period, and (2) there was no sizable $(>10 \%)$ difference between the control run and the incubation experiment (Fig. 1). Using the classic biodegradation experiment protocol $\left(0.7 \mu \mathrm{m} \mathrm{GF} / \mathrm{F}\right.$ filtration) at $23^{\circ} \mathrm{C}$, the BDOC fraction ranged between $0 \%$ and $10 \%$ for all surface waters. The modified procedure $(3 \mu \mathrm{m}$ initial filtration and $0.22 \mu \mathrm{m}$ sampling) did not detect any significant biodegradation for any of the waters studied (the average was $5 \pm 5 \%$ at 4,23 and $37^{\circ} \mathrm{C}-$ Fig. 2b, c, d, respectively). The DIC concentrations remained constant $( \pm 5 \%$ of the initial value) in all experiments, but increased in stream water incubated at $37^{\circ} \mathrm{C}$, where we measured a $\sim 10 \%$ increase over $28 \mathrm{~d}$ of exposure (not shown). This increase was equal to $0.2 \mathrm{mg} \mathrm{L}^{-1}$ of DIC. Note that equivalent decrease in the DOC concentration

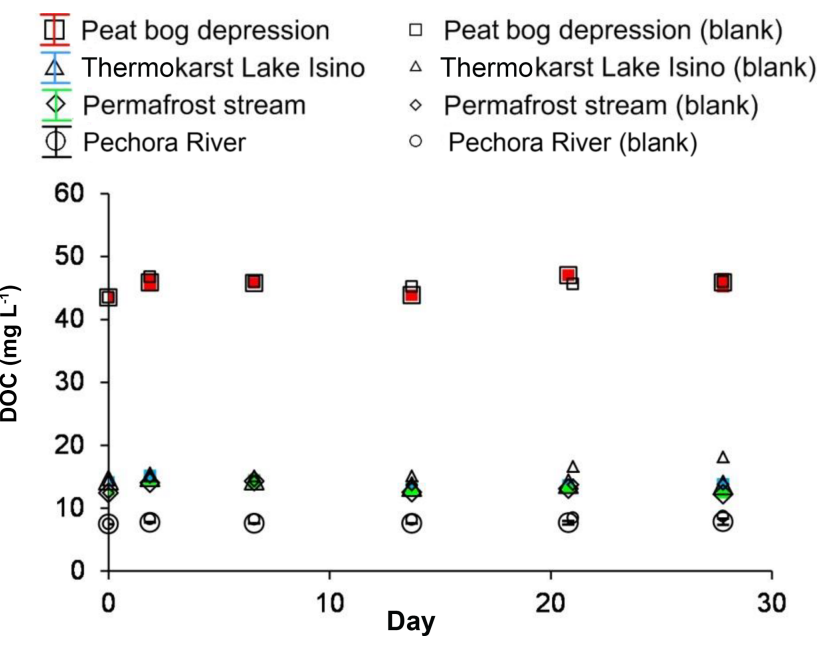

Figure 1. The DOC concentration over time in the biodegradation experiments at $23^{\circ} \mathrm{C}$. The experiments are shown using solid symbols and the control runs are shown using open symbols: red squares represent peat bog depression, green diamonds represent permafrost stream, blue triangles, represent thermokarst Lake Isino and black circles represent the Pechora River. The error bars represent \pm 1 SD of the three replicates and are often within the symbol size.

could not be assessed, presumably due to instrument limitation (the intrinsic uncertainty of NPOC analyses (ca. $2 \%$ of $15 \mathrm{mg} \mathrm{L}^{-1}$ of DOC), which did not allow for the measurement of $\mathrm{C}$ changes smaller than $0.3 \mathrm{mg} \mathrm{L}^{-1}$.

The $U_{254} \mathrm{~nm}$ absorbency of samples over the course of the dark aerobic exposure demonstrated a slight decrease with time (ca. between $5 \%$ and $10 \%$ over $28 \mathrm{~d}$ ) in the peat bog depression using the classic protocol (Fig. S2). However, in all other treatments, the control was indistinguishable from the experimental runs, and the $\mathrm{SUVA}_{254}$ remained constant within the uncertainties of the triplicates (ca. $\pm 5 \%$ to $\pm 10 \%$ ). Similarly, no measurable change in the optical properties of DOM (absorbency at 365, 465, and $665 \mathrm{~nm}$, and in the E4 : E6 ratio) could be detected during the experiment.

The microbial consortium of all systems was dominated by cocci $(0.23 \mu \mathrm{m}$ median size $)$ and rods $(0.96 \mu \mathrm{m} \times 0.20 \mu \mathrm{m})$ as revealed from DAPI fluorescent imaging. The number of culturable oligotrophic bacteria increased by a factor of $\sim 100$ after the first $2-7 \mathrm{~d}$ of exposure at $22^{\circ} \mathrm{C}$, in both the GF/Ffiltered and the $3 \mu \mathrm{m}$ filtered samples, and then remained stable at ca. 10000 to $20000 \mathrm{CFU} \mathrm{mL}^{-1}$ until the end of the experiments (Fig. S3a, c). The highest concentration of oligotrophic bacteria was observed in the Pechora River, whereas the other samples were not significantly different from one another. The $\mathrm{CFU}$ value at $4{ }^{\circ} \mathrm{C}$ ranged between 1000 and $5000 \mathrm{CFU} \mathrm{mL}^{-1}$ and did not demonstrate any clear pattern with time of incubation (Fig. S3b). The number of eutrophic bacteria ranged between 1000 and $15000 \mathrm{CFU} \mathrm{mL}^{-1}$ in the following order: Pechora River $>$ stream $\geq$ peat bog depression $\geq$ thermokarst lake. There was no growth of eutrophic 


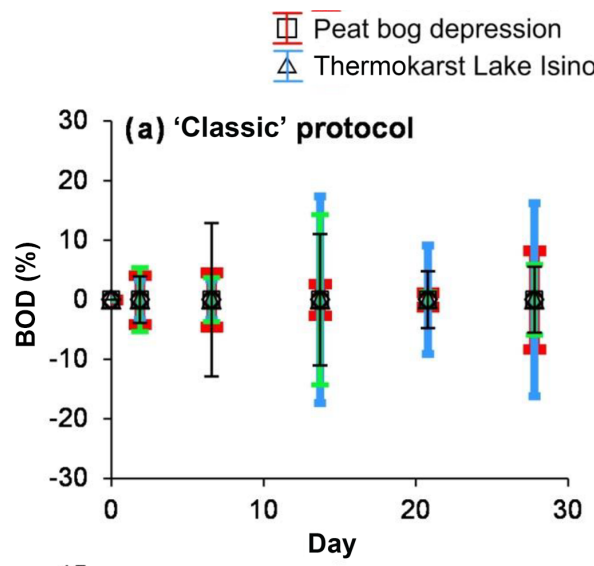

$\bar{\searrow}$ Permafrost stream
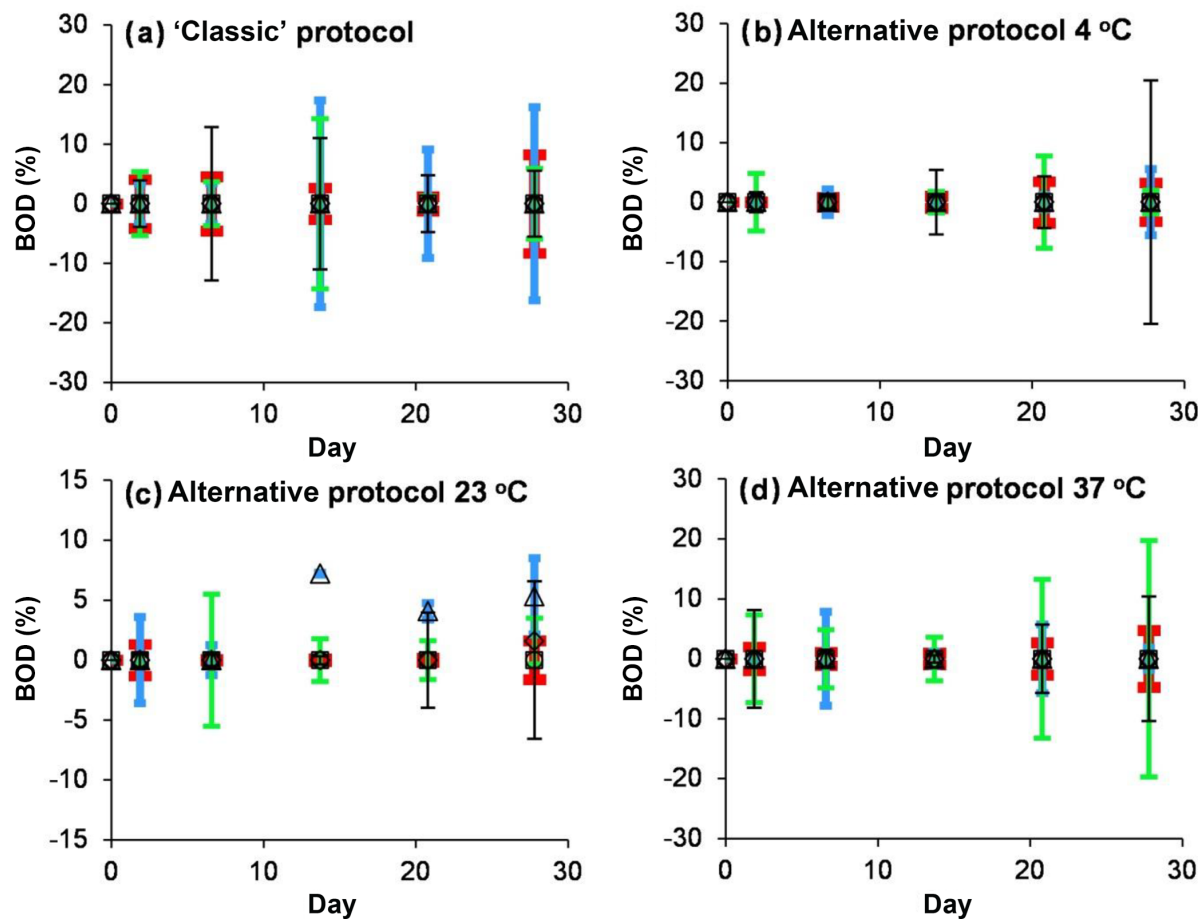

Figure 2. Percentage of biodegradable DOC as a function of time. (a) The classic protocol of $0.7 \mu \mathrm{m} \mathrm{GF} / \mathrm{F}$ filtration at $23^{\circ} \mathrm{C}$; $(\mathbf{b}-\mathbf{d})$ the alternative protocol of $3 \mu \mathrm{m}$ filtered solution incubated at $4{ }^{\circ} \mathrm{C} \mathrm{(b),} 23^{\circ} \mathrm{C}$ (c) and $37^{\circ} \mathrm{C}$ (d) and filtered through $0.22 \mu \mathrm{m}$ at each sampling. The error bars are $\pm 1 \mathrm{SD}$ of the triplicates or, in a few cases, duplicates.

or oligotrophic bacteria at $37^{\circ} \mathrm{C}$. The total cell number gradually increased over the course of the experiment at $22^{\circ} \mathrm{C}$ (Fig. S3d) with the maximum changes observed in the peat bog depression and the Pechora River (by a factor of 30 and 40 , respectively). There was a progressive increase of rodshaped bacillus relative to coccus in the Pechora River and a permafrost stream, whereas the thermokarst lake and peat bog depression did not exhibit any systematic change in dominant bacteria morphologies during the biodegradation experiments. Note that the total cell number in the surface waters of the Bolshezemelskaya Tundra was similar to values obtained in incubation experiments (see Table 1, Fig. S3).

\subsection{Photodegradation of DOM from frozen peatlands}

The $\mathrm{pH}$ of sunlight-exposed samples did not exhibit any systematic variation within $0.5 \mathrm{pH}$ units. The DIC remained fairly stable (within $0.5 \mathrm{mg} \mathrm{L}^{-1}$ ) without any significant change during incubation $\left(R^{2}<0.5 ; p>0.05\right)$, regardless of the type of system, DOC and DIC concentration (not shown). The exposed water remained oxygenated (average $\mathrm{O}_{2}$ saturation close to $90 \%$ ) with no detectable change (i.e., > 10\%) over the course of experiment. Specific conductivity also remained highly stable over full period of exposure.
The bacterial count in photodegradation reactors at the beginning of exposure and after 14 and $28 \mathrm{~d}$ of incubation yielded between 1 and $100 \mathrm{CFU} \mathrm{mL}{ }^{-1}$. This is a factor of 100 to 1000 lower than the number of cells in biodegradation experiments run in non-sterilized waters over the same duration (Sect. 3.1). As such, the microbial degradation was considered negligible for our experimental conditions with respect to sunlight exposure.

There was no sizable decrease in the DOC concentration during the $28 \mathrm{~d}$ of sunlight exposure (Fig. 3a). This relative change in the DOC concentration ranged from $-5 \%$ to $+5 \%$, and it did not exceed the non-systematic variability among the triplicates. Although the triplicates agreed within less than 2\% (the symbol size in Fig. 3), the small change of DOC in the peat depression was similar in the light experiment and the dark control. The \%PDOC (relative to starting solution) as a function of exposure time over the $28 \mathrm{~d}$ of the experiment ranged from $0 \%$ to $5 \%$ in the peat bog depression and $0 \%$ to $10 \%$ in the thermokarst lake and permafrost spring (Fig. 3b).

The $\mathrm{SUVA}_{254 \mathrm{~nm}}$ in photodegradation experiments decreased much more strongly than the DOC. The SUVA decrease relative to the control was most pronounced in the permafrost stream (Fig. 4). The optical properties of DOC demonstrated a sizable decrease of the $\mathrm{E}_{365}: \mathrm{E}_{470}$ ratio cor- 


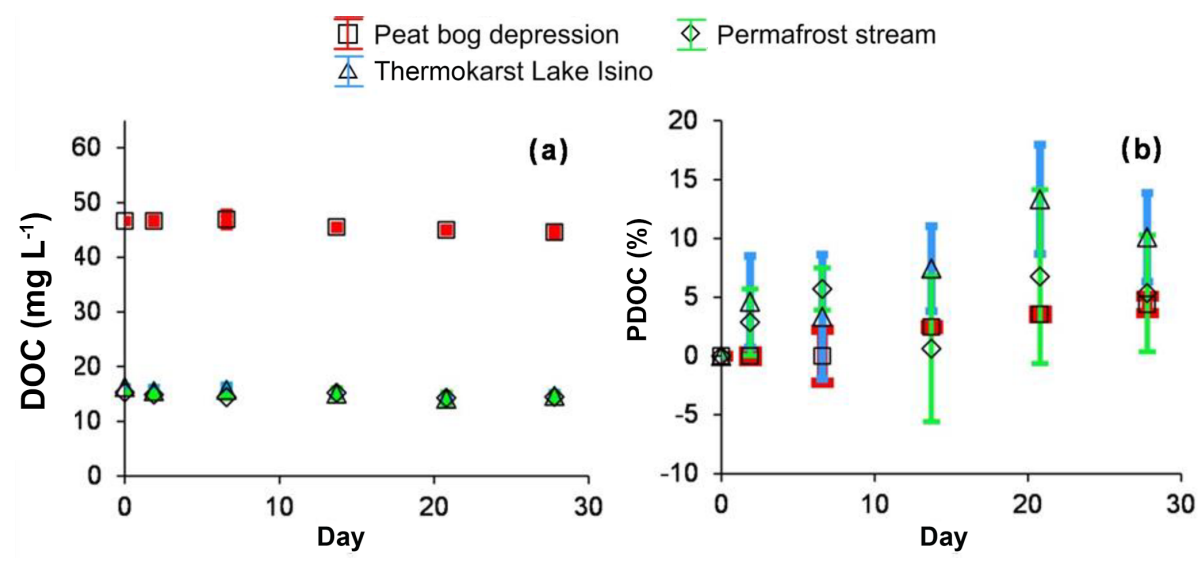

Figure 3. Concentration (a) and percentage (b) of degradable DOC in photodegradation experiments. The experiments are shown using solid symbols and the control runs are shown using open symbols: red squares represent the peat bog depression, green diamonds represent the permafrost stream and triangles represent the thermokarst Lake Isino. The error bars are $\pm 1 \mathrm{SD}$ of the triplicates.

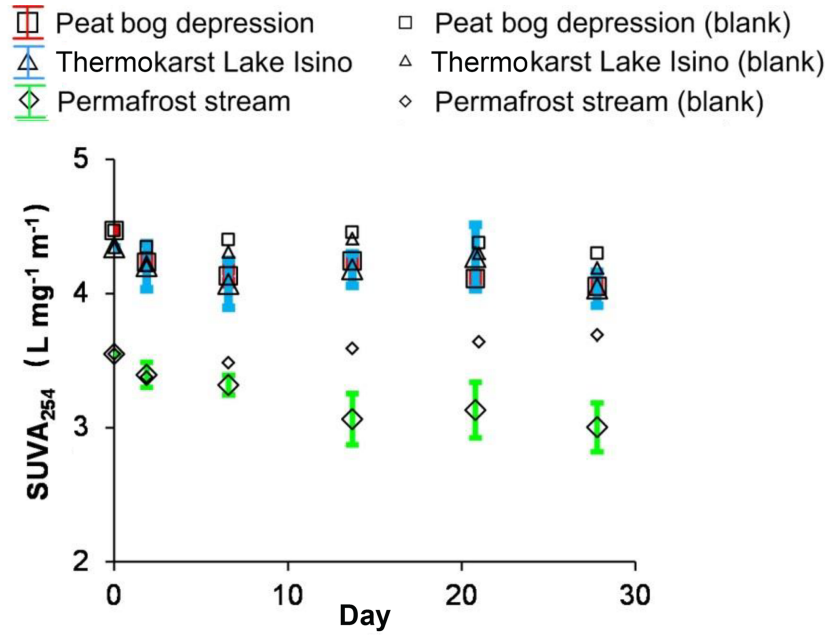

Figure 4. SUVA $_{254} \mathrm{~nm}$ over time in photodegradation experiments. The error bars are \pm 1 SD of the triplicates.

responding to UV/vis absorbing functional groups (Fig. S4a), which was consistent with decreasing $\mathrm{SUVA}_{254 \mathrm{~nm}}$ during sunlight exposure. The $\mathrm{E}_{254}: \mathrm{E}_{436}$ ratio, corresponding to autochthonous versus terrestrial DOM, did not demonstrate any sizable change over the course of experiment (Fig. S4b).

Most of the major and trace elements did not show any significant change (at $p<0.05$ ) in concentration over the photodegradation experiments. Only a few nutrients $(\mathrm{P}, \mathrm{Fe}$, $\mathrm{Zn}$ and $\mathrm{B}$ ) and trace metals ( $\mathrm{Zn}, \mathrm{Ti}, \mathrm{V}, \mathrm{Zr}, \mathrm{Nb}$ and $\mathrm{Th}$ ) demonstrated a decrease in concentration. The decrease of Fe was most pronounced in the permafrost stream, and did not occur in the permafrost depression (Fig. 5a), whereas total dissolved phosphorus systematically decreased, by $20 \%$ to $50 \%$, over the $28 \mathrm{~d}$ of sunlight exposure in the permafrost depression, thermokarst lake and permafrost stream (Fig. 5b). A decrease in $\mathrm{Ti}, \mathrm{Zn}, \mathrm{Nb}$ and $\mathrm{Th}$ also occurred in the thermokarst lake and permafrost stream (not shown). Overall, the magnitude of the decrease in $\mathrm{P}, \mathrm{Fe}, \mathrm{Ti}, \mathrm{V}$ and $\mathrm{Zn}$ in photodegradation experiments occurred in the following order: permafrost stream $>$ thermokarst lake $>$ permafrost depression.

\section{Discussion}

\subsection{High stability of DOM to biodegradation in surface waters from frozen peatland}

The unexpected result of this study was the very low BDOC fraction, measured not only in a large river (Pechora) but also in a small stream, a thermokarst lake and in peatland depressions formed due to permafrost subsidence. According to a compilation of available biodegradation studies, the BDOC fraction ( $28 \mathrm{~d}$ exposure period) ranges from $3 \%$ to $18 \%$ (mean $13 \%$ ) in waters of a continuous permafrost zone and from $5 \%$ to $15 \%$ (mean $14 \%$ ) in a discontinuous permafrost zone (Vonk et al., 2015). This is higher than the $0 \%$ to $10 \%$ BDOC measured for all water bodies from the discontinuous permafrost zone in this study. Note that very few biodegradability studies in aquatic systems have dealt with frozen peatlands, and all previous incubation experiments have used water from mountainous regions on mineral soils in Scandinavia, on Alaskan slopes and in Canada, in yedoma regions in eastern Siberia, or in the Yenisey Basin. Only one former biodegradation study in a peat mire context demonstrated the sizable bioavailability of soil leachate to lake water bacteria (Roehm et al., 2009); however, Roehm et al. (2009) did not deal with a pure aquatic end-member, as was the case in this study. Instead, the BDOC of frozen peatland surface waters measured for the Bolshezemelskaya Tundra inland waters was comparable with the value suggested by Vonk et al. (2015) for non-permafrost aquatic DOC (0\%$1 \%)$. 


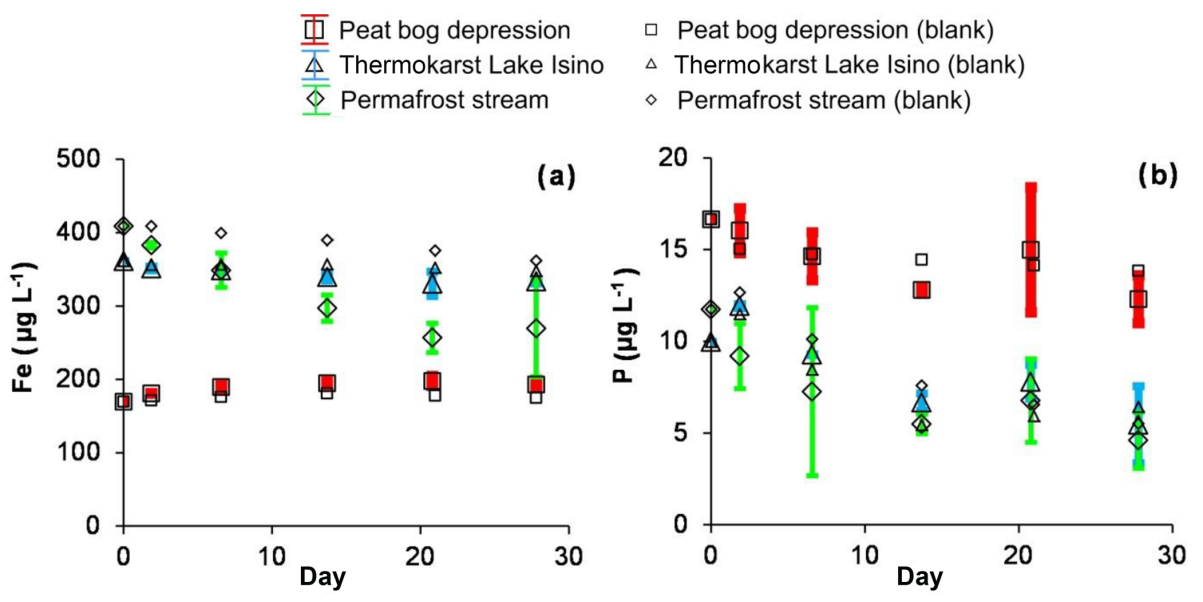

Figure 5. Fe (a) and P (b) concentrations over time in photodegradation experiments. The error bars are \pm 1 SD of the triplicates.

Another important point revealed in previous work on biodegradation in Arctic waters was that aquatic BDOC in large streams and rivers decreased as the Arctic summer progressed (Vonk et al., 2015), although this pattern was absent for soil leachates and small streams. In our case, thermokarst Lake Isino and the Pechora River can be considered to be sufficiently large hydrological systems. The sampling was performed at the end of July, which is already summer baseflow period, and, as such, the $0 \%$ to $5 \%$ biodegradable DOC measured for Lake Isino and the Pechora River in this study is comparable with the $0 \%$ to $20 \%$ BDOC loss reported in large streams and rivers on Julian day $\sim 200$ (Vonk et al., 2015). However, small stream and permafrost subsidence clearly remain at the very low end of BDOC \% loss reported for soils and streams in summer. In the estuarine zone of largest European Arctic permafrostfree river, the Severnaya Dvina, there was no measurable biodegradation in spring, when the DOM was dominated by allochthonous sources, but a $15 \%$ to $20 \%$ decrease of DOC occurred during first $300 \mathrm{~h}$ in river water collected in $\mathrm{Au}-$ gust, when sizable phytoplankton productivity was observed (Shirokova et al., 2017b). In laboratory experiments with individual cultures, moss and peat leachates were also sizably biodegraded over 1-2 d of exposure (Shirokova et al., 2017a), whereas the same bacterial species were not capable of degrading DOM from surface waters draining peatland and moss-covered bogs (Oleinikova et al., 2018). Following a recommended protocol for biodegradation assays (Vonk et al., 2015), in this work we incubated natural water without nutrients. This creates a potential bias regarding the application of obtained results to various subarctic settings. For example, one should note that nutrients and labile DOM addition downstream (away from the oligotrophic bogs) can increase the capacity of biodegradation and related $\mathrm{CO}_{2}$ emission in a large river, before its discharge to the Arctic Ocean. Furthermore, it is possible that the input of bio-labile DOC from terrestrial vegetation may enhance the bioavailability of stable DOC (e.g., Textor et al., 2018) in natural settings, although this effect could not be tested in this study.

Mechanistic reasons for the extremely low bioavailability of DOC from studied peatlands remain unclear and require an in-depth analysis of the DOM molecular structure and stoichiometry as well as high-resolution microbial approaches. It is known that the DOM released from frozen soils contains high proportions of biologically labile proteinlike and photochemically reactive aromatic substances (Gao et al., 2018). Following the pioneering study of Ward et al. (2017), we hypothesize that, similar to DOC from the organic (non-permafrost) layer, the concentration of highly labile, aliphatic-like DOC in surface waters of frozen peatlands is too low to sustain microbial populations, or that this aquatic DOC, remaining after the microbial processing of soil pore-water DOC, is of low lability for microbes capable of degrading aliphatic-like DOC and inhabiting the aerobic zone of permafrost surface waters. The constant pattern of $\mathrm{UV}_{254}$ absorbency in biodegradation experiments was consistent with the negligible change in BDOC over the $28 \mathrm{~d}$ incubation period. In comparison, the biodegradation of peat water from the European boreal zone was associated with an increase in SUVA by up to $7.4 \%$, which also implies an increase in the proportion of aromatic compounds (Hulatt et al., 2014). The total bacterial number in the surface waters studied $\left(0.5\right.$ to $5 \times 10^{6}$ cell $\left.\mathrm{mL}^{-1}\right)$ is in excellent agreement with other studies on thermokarst peatland lake waters (Deshpande et al., 2016). Following these researchers, we suggest that the reason for the low biodegradability of peatland humic waters is that the majority of the active bacteria are associated with particles $(>3 \mu \mathrm{m})$ rather than present as free-living cells $(<1 \mu \mathrm{m})$ capable of processing DOC. In addition, the bacterial communities are not just shaped by size fractionation by filtration, but also by the presence or absence of bacterial grazers (Dean et al., 2018). However, further mechanistic studies of model aquatic bacterial communities 
capable of affecting the degradation of DOM from different terrestrial sources are necessary (Logue et al., 2016).

Interestingly, there was no measurable difference in BDOC at 4,23 and $37^{\circ} \mathrm{C}$, as the proportion of BDOC at all temperatures for each system was below 5\%-10\%. This result allows for the preliminary prediction of the possible consequence of climate change and surface water heating at high latitudes. In a short-term climate warmings scenario, or assuming the fast heating of surface waters due to prolonged heat waves or drought occurring both in European, permafrost-free (Shirokova et al., 2013a) and western Siberian (Pokrovsky et al., 2013) permafrost-bearing peatlands, we do not foresee any measurable change in the biodegradability of DOM from the water column. Under even the most extreme heating scenario for thermokarst lakes, rivers and depressions of the frozen peatland territories, the short-term bioprocessing of aquatic DOM may remain close to zero.

\subsection{Negligible impact of photodegradation on DOM transformation in inland waters of frozen peatlands}

The second main result of this work was the high stability of surface water DOM to sunlight exposure. Over the $28 \mathrm{~d}$ incubation period in outdoor pools at conditions corresponding to the surface water layer $(<0.05 \mathrm{~m}$ depth) of thermokarst lakes and streams of the permafrost zone, the change in the DOC concentration was less than $5 \%-10 \%$ of the initial value and was not distinguishable from that of the dark control (Fig. 3a, b). Therefore, the DOM of the frozen peatland is quite refractory and not subject to measurable photodegradation over 4 weeks of exposure. This period is comparable with the water residence time in small depressions of frozen peatlands (Novikov et al., 2009) and small thermokarst thaw ponds of frozen palsa peat bogs (Manasypov et al., 2015), but it is much higher than the water travel time in small streams ( $<10 \mathrm{~km}$ long) and in the lower reaches of the Pechora River, from the sampling site to the Arctic Ocean (ca. several days). This result apparently contradicts the recent paradigm that photochemical oxidation may account for $70 \%$ to $95 \%$ of total DOC processed in the water column of Arctic lakes, rivers and soils (Cory et al., 2013, 2014; Ward and Cory, 2016; Ward et al., 2017). However, the conclusion of this group of authors is based on a study of distilled water leachates of mineral soils, headwater streams, fresh permafrost thaw sites and lakes of northern Alaskan slopes, developed on mineral substrates. In contrast, the results of DOM photolysis in polygonal and runnel ponds located in frozen peatlands ( $2 \mathrm{~m}$ peat, 40-60 cm active layer thickness) of continuous permafrost regions (Canada High Arctic) demonstrated a relatively fast decay of water color and fluorescence, but an insignificant loss of DOC over a $12 \mathrm{~d}$ exposure period (Laurion and Mladenov, 2013). Recently, no measurable photochemical loss of ancient permafrost DOC has been revealed in the thawing yedoma permafrost sites of the Kolyma River, or in its tributaries and streams (Stubbins et al., 2017). Another recent study of DOM photodegradation in boreal highlatitude peatland streams of the White Sea watershed demonstrated only a $10 \%$ decrease in the DOC concentration over a $10 \mathrm{~d}$ incubation period under sunlight (Oleinikova et al., 2017). In the estuarine zone of the largest European Arctic river draining wetland- and forest-dominated permafrost-free territory (Severnaya Dvina), we did not find any measurable photodegradation of DOM over 1 month of exposure (Chupakova et al., 2018). This comparison clearly demonstrates highly contrasting DOM photolability between the aquatic systems of North America, draining through mineral soil substrates, and that of boreal and subarctic peatlands.

Furthermore, due to the high homogeneity of the organic substrate surrounding the waters studied and the similar allochthonous origin of the DOM in all surface waters of frozen peatlands, there was no dramatic difference in the DOM photo-degradability over the hydrological continuum in the northeastern European Arctic, which also contrasts with results obtained in aquatic systems on mineral soils (Cory et al., 2007, 2013; Reader et al., 2014). It is possible that either (1) photochemical degradation of humic peat waters occurs very fast during the first hours to days upon their exposure to sunlight, or (2) that the nature of DOM is so refractory that much longer exposure periods, of the order of several months to years (as in the Arctic coast) are necessary to photo-degrade the DOM from frozen peatlands. The first explanation is consistent with recent experiments on the photodegradation of fresh peat mire water, collected in the Taiga region of northwestern Russia, where about $50 \%$ of bog water DOC was photo-degraded over $2 \mathrm{~d}$ of exposure to sunlight (Oleinikova et al., 2017).

As such, it is possible that all surface waters sampled for the experiments in this study, including stagnant water in permafrost depression, had already undergone contact with sunlight for more than several days and had therefore became photo-resistant. Assuming the maximal possible DOC loss due to photolysis assessed in our experiments $\left(0.1 \mathrm{mg} \mathrm{C} \mathrm{L}^{-1} \mathrm{~d}^{-1}\right.$ corresponding to a loss of $3 \mathrm{mg} \mathrm{L}^{-1}$ over $28 \mathrm{~d}$ ) and the light penetration depth of $0.5 \mathrm{~m}$, which is comparable to the typical depth of the water bodies studied, photodegradation would contribute to less than $10 \%$ of the total $\mathrm{CO}_{2}$ emission flux from the water surfaces of frozen peatlands $\left(0.4-0.8 \mathrm{~g} \mathrm{C} \mathrm{m}^{-2} \mathrm{~d}^{-1}\right.$ in this work; 0.8 to $4.4 \mathrm{C} \mathrm{m}^{-2} \mathrm{~d}^{-1}$ in western Siberian rivers and streams, located in a very similar environmental context - frozen peat bogs; Serikova et al., 2018). The maximal PDOC value measured in this work is also at the lower end of the range of the DOM photodegradation contribution to the $\mathrm{C}$ flux in north European boreal and subarctic settings. Thus, DIC annual photoproduction contributed between $1 \%$ and $8 \%$ of $\mathrm{CO}_{2}$ emissions from a humic lake in the south of Sweden (Groeneveld et al., 2016), and globally, in the boreal and subarctic zone, sunlight-induced $\mathrm{CO}_{2}$ emissions represent about one-tenth of 
the $\mathrm{CO}_{2}$ emissions from lakes and reservoirs (Koehler et al., 2014).

The evolution of the optical properties of DOM as a function of exposure time in different samples was consistent with the mechanisms of photosensitive DOM removal during irradiation. The $\mathrm{E}_{365}: \mathrm{E}_{470}$ ratio is known to correlate with the degree of condensation of DOM aromatic groups and with the degree of humification (Chin et al., 1994; Hur et al., 2006), whereas $\mathrm{UV}_{254}$ is used as proxy for aromatic $\mathrm{C}$ and the source of DOM (Chen et al., 1977; Uyguner and Bekbolet, 2005). The optical properties of DOC were much less conservative under sunlight exposure compared with the total dissolved $\mathrm{C}$ concentration, as $\mathrm{UV}_{254 \mathrm{~nm}}$ and the $\mathrm{E}_{365}$ : $\mathrm{E}_{470}$ ratio sizably decreased over the course of the experiments. Numerous studies of allochthonous riverine DOM also revealed that photodegradation of colored DOM (CDOM) and $\mathrm{SUVA}_{254}$ were much greater than DOC losses (Spencer et al., 2009; Reche et al., 2000; Vähätalo and Wetzel, 2004; Mostofa et al., 2011; Bittar et al., 2015; Gareis and Lesack, 2018). A decrease of $E_{365}: E_{470}$ corresponded to a removal of UV rather than visual light absorbing functional groups, whereas a constant pattern of the $\mathrm{E}_{254}: \mathrm{E}_{436}$ ratio within the hydrological continuum - depression $\rightarrow$ stream $\rightarrow$ lake $\rightarrow$ river - was consistent with a lack of autochthonous DOM in all water bodies studied, which were dominated by terrestrial (aromatic) DOM from peat horizons. Overall, our observations confirm the conclusion reached by a recent compilation of available data from around the world: degradation processes act preferentially on CDOM rather than on the DOC concentration (Massicotte et al., 2017; Oleinikova et al., 2017).

In contrast to DOC, the sizable removal of dissolved $\mathrm{P}$ and Fe along with some related trace elements ( $\mathrm{Ti}, \mathrm{V}, \mathrm{Zn}$ and $\mathrm{Nb}$ ) during the photolysis of surface waters reflects the transformation and coagulation of Fe-rich colloids, which behave independently of organic colloids in humic waters (Vasyukova et al., 2010; Pokrovsky et al., 2016). This precipitation of Fe hydroxides along with $\mathrm{P}$ and insoluble trace elements was most pronounced in the permafrost stream, which had the highest $\mathrm{pH}$. In this stream, Fe(III) hydroxide was not stable due to pronounced hydrolysis. After the photolytic removal of a small amount of DOM that stabilized colloidal Fe (Oleinikova et al., 2017), Fe hydroxide could coagulate and coprecipitate $\mathrm{P}$ and some trace elements.

\subsection{Lack of bio- and photodegradation in humic surface waters of frozen peat bogs despite sizable $\mathrm{CO}_{2}$ emission}

The main result of the present study is that, despite the wellknown supersaturation of lentic and lotic waters of frozen peatlands to atmospheric $p \mathrm{CO}_{2}$ (Serikova et al., 2018, 2019), these waters exhibit negligible bio- and photo-degradability over a timescale ( $28 \mathrm{~d}$ ) comparable to or exceeding the water residence time in various reservoirs. For consistency with other studies at high latitudes, we assessed the bio- and photo-degradability of DOM during the midsummer period. Not accounting for the spring freshet, which represents more than $60 \%$ of the annual DOM transport in similar boreal and subarctic rivers of European Russia (Pokrovsky et al., 2010) and western Siberia (Pokrovsky et al., 2015; Vorobyev et al., 2019), may create a substantial bias when extending our results to other territories of the subarctic during the full open water period. However, it was recently shown that during spring flood, the DOM in the largest European Arctic River, the Severnaya Dvina, which is similar to the Pechora River, is not at all biodegradable (Shirokova et al., 2017b). Moreover, the springtime period does not exhibit any particularly high $\mathrm{C}$ concentrations in the thaw ponds and thermokarst lake waters of frozen peatlands (Manasypov et al., 2015), and $\mathrm{CO}_{2}$ emissions from rivers and lakes of the permafrost-affected wetlands of western Siberia were not much higher in spring than during other seasons (Serikova et al., 2018, 2019). Therefore, although our seasonally restricted data set is not representative for the pan-Arctic environment, and further studies with high spatial resolution across different climate zones are needed (see examples in Lapierre and del Giorgio, 2014), our findings are at odds with the dominant paradigm that bioand photodegradation control the DOC removal from Arctic aquatic ecosystems (Abbot et al., 2014; Cory et al., 2014; Spencer et al., 2015). Given the incontestable bio- and photodegradability of peat pore waters and frozen soil extracts reported across the Arctic (Vonk et al., 2015; Selvam et al., 2017), this strongly suggests that the DOM which arrives to small rivers and even permafrost depressions via lateral peat soil outflux is already highly degraded. This is consistent with the general idea that the rates of DOM photochemical alteration and the rates of microbial responses to altered DOM are typically rapid, from minutes to days (Cory and Kling, 2018). As such, the majority of elevated $\mathrm{CO}_{2}$ measured in the surface waters of the permafrost peat landscape originates from the degradation of soil water DOM once it enters open surface water. This is especially true for photooxidation, which is not likely to occur in the soil.

We believe that the degradation of soil DOM in the surface waters of frozen peatlands occurs very fast and completes within first hours or days. This is shorter than the residence time of water in permafrost depressions, thaw ponds and rivers (Manasypov et al., 2015). As a result, we did not detect sizable bio- and photodegradation of residual DOM in various types of inland waters from permafrost landscapes. In order to explain persistent $\mathrm{CO}_{2}$ supersaturation of inland waters from peatlands, we suggest that the benthic respiration of stream, lake and river sediments produces a sizable amount of $\mathrm{CO}_{2}$ - thus increasing the overall $\mathrm{C}$ emission potential of the aquatic systems (MacIntyre et al., 2018; Valle et al., 2018). For example, anaerobic C mineralization of thermokarst lake sediments is fairly well established in the discontinuous permafrost zone of peat bogs in western Siberia (Audry et al., 2011) and Canada (Deshpande et al., 
2017). Note that the potential for dark DOM chemical oxidation in Fe-rich organic-rich waters facing redox oscillation (i.e., Page et al., 2012) is rather low in the thermokarst waters studied; therefore, they remain essentially oxic over the full depth of the water column during the unfrozen period of the year.

The findings of this study and the widely reported dominance of non-biodegradable DOC (0\%-1\% BDOC) in large rivers and streams of the non-permafrost zone (Vonk et al., 2015 ) suggest that (1) the majority of BDOC is degraded before its arrival to large aquatic reservoirs, and (2) the $\mathrm{CO}_{2}$ supersaturation and emission of surface waters from frozen peatlands is due to soil pore water and sediment respiration rather than aerobic bio- and photodegradation of DOM in the water column. Furthermore, the lack of an increase in the BDOC fraction during the temperature rise from 4 to $37^{\circ} \mathrm{C}$ implies that the heating of peat surface waters will be a minor factor of the overall $\mathrm{CO}_{2}$ balance, within the climate warming scenario. Instead, the change of the water path and residence time in pore waters of frozen peatlands, the rate of supra-permafrost water delivery, and the magnitude of benthic respiration in large rivers and thermokarst lakes may control the $\mathrm{CO}_{2}$ emission from inland waters.

\section{Conclusions}

This work revealed the high resistance of surface waters collected in permafrost peatland to both bio- and photodegradation. Less than $5 \%-10 \%$ of the initial aquatic DOC was removed over a 1-month period of dark aerobic incubation at 4,22 and $37^{\circ} \mathrm{C}$ as well as during the sunlight exposure of sterile-filtered waters. In contrast to the expected differences in bio- and photolability between small permafrost depressions, streams, a large lake and the Pechora River, there was no measurable difference in the surface water BDOC concentration along the hydrological continuum. The contribution of aerobic DOM biodegradation within the water column to the observed $\mathrm{CO}_{2}$ supersaturations and net $\mathrm{CO}_{2}$ emission fluxes from bog water, lakes, streams and rivers of peatland territories located within discontinuous permafrost zone is less than $10 \%$. Despite the decrease in CDOM during photolysis, this process does not significantly contribute to the total DOC degradation and $\mathrm{C}$ emission from the surface of inland waters of frozen peatlands.

We hypothesize that the refractory nature of DOM from frozen peatlands, which is already processed in soil waters before arriving to lentic and lotic surface reservoirs, creates unfavorable conditions for biodegradation. The reason for the high stability of DOM from frozen peatland to photolysis is less clear but can be linked to the fast photodegradation of peat bog and soil shallow (underground) waters after their exposure to the surface, occurring within the first hours to days.
We conclude a negligible impact of DOM bio- and photodegradation on $\mathrm{CO}_{2}$ emission in surface waters of frozen peatlands. This calls for future work to quantify the combined bio- and photolability of peat pore waters, thawing soil ice and supra-permafrost flow, which deliver the DOM to the rivers, lakes and depressions.

Data availability. Please note that all the data obtained in this work are available in the main text and in the Supplement of this article.

Supplement. The supplement related to this article is available online at: https://doi.org/10.5194/bg-16-2511-2019-supplement.

Author contributions. LSS and OSP contributed to the study design. LSS organized sampling campaigns and logistics. LSS, AVC, SAZ, and NVN contributed to sampling. LSS and CC analyzed the DOC and DIC; DPR analyzed the SUVA and optical properties of samples. JK complemented the data with material from the literature. SSL analyzed data. AVC prepared the figures and tables. LSS wrote the paper. JK and OSP helped interpret the results. All authors commented on the paper.

Competing interests. The authors declare that they have no conflict of interest.

Financial support. This work was supported by RFFI (RFBR; grant nos. 17-05-00348_a, 17-05-00342_a, and 18-05-01041), Program FANO (grant no. 0409-2015-0140), and UroRAN (grant no. 18-9-5-29). Additional funding was provided by "JPI Climate" initiative, which is financially supported by the Swedish Research Council VR (grant no. 325-2014-6898).

Review statement. This paper was edited by Steven Bouillon and reviewed by Joshua Dean and one anonymous referee.

\section{References}

Abbott, B. W., Larouche, J. R., Jones, J. B., Bowden, W. B., and Balser, A. W.: Elevated dissolved organic carbon biodegradability from thawing and collapsing permafrost, J. Geophys. Res., 119, 2049-2063, 2014.

Amado, A. M., Cotner, J. B., Cory, R. M., Edhlund, B. L., and McNeill, K.: Disentangling the interactions between photochemical and bacterial degradation of dissolved organic matter: amino acids play a central role, Microb. Ecol., 69, 554-566, 2014.

Andersson, M. G. I., Catalán, N., Rahman, Z., Tranvik, L. J., and Lindström, E. S.: Effects of sterilization on dissolved organic carbon (DOC) composition and bacterial utilization of DOC from lakes, Aquat. Microb. Ecol., 82, 199-208, 2018. 
Ask, J., Karlsson, J., and Jansson, M.: Net ecosystem production in clear-water and brown-water lakes, Global Biogeochem. Cy., 26, GB1017, https://doi.org/10.1029/2010GB003951, 2012.

Audry, S., Pokrovsky, O. S., Shirokova, L. S., Kirpotin, S. N., and Dupré, B.: Organic matter mineralization and trace element post-depositional redistribution in Western Siberia thermokarst lake sediments, Biogeosciences, 8, 3341-3358, https://doi.org/10.5194/bg-8-3341-2011, 2011.

Berggren, M., Laudon, H., Haei, M., Ström, L., and Jansson, M.: Efficient aquatic bacterial metabolism of dissolved low-molecularweight compounds from terrestrial sources, ISME J., 4, 408-416, 2010.

Bittar, T. B., Vieira, A. A. H., Stubbins, A., and Mopper, K.: Competition between photochemical and biological degradation of dissolved organic matter from the cyanobacteria Microcystis aeruginosa, Limnol. Oceanogr., 60, 1172-1194, 2015.

Brittain, J. F., Gislason, G. M., Ponomarev, V. I., Bogen, J., Jensen, A. J., Khokhlova, L. G., Kochanov, S. K., Kokovkin, A. V., Melvold, K., Olafsson, J. S., Pettersson, L.-E., and Stenina, A. S.: Arctic Rivers, in: Rivers of Europe, edited by: Tockner, K., Uehlinger, U., and Robinson, C.T., chap. 9, 337-379, Academic Press Elsevier, Amsterdam, the Netherlands, 2009.

Chen, Y., Senesi, N., and Schnitzer, M.: Information provided on humic substances by E4/E6 ratios, Soil Sci. Soc. Am. J., 41, 352-358, 1977.

Chin, Y.-P., Aiken, G., and O'Loughlin, E.: Molecular weight, polydispersity, and spectroscopic properties of aquatic humic substances. Environ. Sci. Technol., 28, 1853-1858, 1994.

Chupakova, A. A., Chupakov, A. V., Neverova, N. V., Shirokova, L. S., and Pokrovsky, O. S.: Photodegradation of river dissolved organic matter and trace metals in the largest European Arctic estuary, Sci. Total Environ., 622-623, 1343-1352, 2018.

Cole, J. J. and Caraco, N. : Atmospheric exchange of carbon dioxide in a low-wind oligotrophic lake measured by the addition of SF6, Limnol. Oceanogr., 43, 647-656, 1998.

Cory, R. M. and Kling, G. W.: Interactions between sunlight and microorganisms influence dissolved organic matter degradation along the aquatic continuum, Limnol. Oceanogr. Lett., 3, 102116, 2018.

Cory, R. M., McKnight, D., Chin, Y. P., Miller, P., and Jaros, C. L.: Chemical characteristics of fulvic acids from Arctic surface waters: Microbial contributions and photochemical transformations, J. Geophys. Res., 112, G04S51, https://doi.org/10.1029/2006JG000343, 2007.

Cory, R. M., Crump, B. C., Dobkowski, J. A., and Kling, G. W.: Surface exposure to sunlight stimulates $\mathrm{CO}_{2}$ release from permafrost soil carbon in the Arctic, P. Natl. Acad. Sci. USA, 110, 3429-3434, 2013.

Cory, R. M., Ward, C. P., Crump, B. C., and Kling, G. W.: Sunlight controls water column processing of carbon in arctic fresh waters, Science, 345, 925-928, 2014.

Cory, R. M., Harrold, K. H., Neilson, B. T., and Kling, G. W.: Controls on dissolved organic matter (DOM) degradation in a headwater stream: the influence of photochemical and hydrological conditions in determining light-limitation or substratelimitation of photo-degradation, Biogeosciences, 12, 6669-6685, https://doi.org/10.5194/bg-12-6669-2015, 2015.

Dean, J. F., van Hal, J. R., Dolman, A. J., Aerts, R., and Weedon, J. T.: Filtration artefacts in bacterial community composition can affect the outcome of dissolved organic matter biolability assays, Biogeosciences, 15, 7141-7154, https://doi.org/10.5194/bg-157141-2018, 2018.

Dean, J. F., Garnett, M. H., Spyrakos, E., and Billett, M. F.: The potential hidden age of dissolved organic carbon exported by peatland streams, J. Geophys. Res.-Biogeo., 124, 328-341, 2019.

Deshpande, B. N., Crevecoeur, S., Matveev, A., and Vincent, W. F.: Bacterial production in subarctic peatland lakes enriched by thawing permafrost, Biogeosciences, 13, 4411-4427, https://doi.org/10.5194/bg-13-4411-2016, 2016.

Deshpande, B. N., Maps, F., Matveev, A., and Vincent, W. F.: Oxygen depletion in subarctic peatland thaw lakes, Arctic Science, 3, 406-428, 2017.

Drake, T. W., Holmes, R. M., Zhulidov, A. V., Gurtovaya, T., Raymond, P. A., McClelland, J. W., and Spencer, R. G. M.: Multidecadal climate-induced changes in Arctic tundra lake geochemistry and geomorphology, Limnol. Oceanogr., 64, S179-S191, 2019.

Gao, L., Zhou, Z., Reyes, A. V., and Guo, L.: Yields and characterization of dissolved organic matter from different aged soils in northern Alaska, J. Geophys. Res.-Biogeo., 123, 2035-2052, 2018.

Gareis, J. A. L. and Lesack, L. F. W.: Photodegraded dissolved organic matter from peak freshet river discharge as a substrate for bacterial production in a lake-rich great Arctic delta, Arctic Science, 4, 557-583, 2018.

Groeneveld, M., Tranvik, L., Natchimuthu, S., and Koehler, B.: Photochemical mineralisation in a boreal brown water lake: considerable temporal variability and minor contribution to carbon dioxide production, Biogeosciences, 13, 3931-3943, https://doi.org/10.5194/bg-13-3931-2016, 2016.

Helms, J. R., Stubbins, A., Ritchie, J. D., Minor, E. C., Kieber, D. J., and Mopper, K.: Asorption spectral slopes and slope ratios as indicators of molecular weight, source, and photobleaching of chromophoric dissolved organic matter, Limnol. Oceanogr., 53, 955-969, 2008.

Holmes, R. M., McClelland, J. W., Raymond, P. A., Frazer, B. B., Peterson, B. J., and Stieglitz, M.: Lability of DOC transported by Alaskan rivers to the Arctic Ocean, Geophys. Res. Lett., 35, L03402, https://doi.org/10.1029/2007GL032837, 2008.

Hulatt, C. J., Kaartokallio, H., Asmala, E., Autio, R., Stedmon, C. A., Sonninen, E., Oinonen, M., and Thomas, D. N.: Bioavailability and radiocarbon age of fluvial dissolved organic matter (DOM) from a northern peatland-dominated catchment: effect of land-use change, Aquat. Sci., 76, 393-404, 2014.

Hur, J., Williams, M. A., and Schlautman, M. A.: Evaluating spectroscopic and chromatographic techniques to resolve dissolved organic matter via end member mixing analysis, Chemosphere, 63, 387-402, 2006.

Ilina, S. M., Drozdova, O. Yu., Lapitsky, S. A., Alekhin, Yu. V., Demin, V. V., Zavgorodnaya, Yu. A., Shirokova, L. S., Viers, J., and Pokrovsky, O. S.: Size fractionation and optical properties of dissolved organic matter in the continuum soil solution-bogriver and terminal lake of a boreal watershed, Org. Geochem., 66, 14-24, 2014.

Kaiser, K., Canedo-Oropeza, M., McMahon, R., and Amon, R. M. W.: Origins and transformations of dissolved organic matter in large Arctic rivers, Sci. Rep.-UK, 7, 13064, https://doi.org/10.1038/s41598-017-12729-1, 2017. 
Karlsson, J., Jansson, M., and Jonsson, A.: Respiration of allochthonous organic carbon in unproductive forest lakes determined by the Keeling plot method, Limnol. Oceanogr., 52, 603608, 2007.

Koehler, B., Landelius, T., Weyhenmeyer, G. A., Machida, N., and Tranvik, L. J.: Sunlight-induced carbon dioxide emissions from inland waters, Global Biogeochem. Cy., 28, 696-711, 2014.

Köhler, S., Buffam, I., Jonsson, A., and Bishop, K.: Photochemical and microbial processing of stream and soil water dissolved organic matter in a boreal forested catchment in northern Sweden, Aquat. Sci., 64, 269-281, 2002.

Lapierre, J.-F. and del Giorgio, P. A.: Partial coupling and differential regulation of biologically and photochemically labile dissolved organic carbon across boreal aquatic networks, Biogeosciences, 11, 5969-5985, https://doi.org/10.5194/bg-11-59692014, 2014.

Lapierre, J.-F., Guillemette, F., Berggren, M., and del Giorgio, P. A.: Increases in terrestrially derived carbon stimulate organic carbon processing and $\mathrm{CO}_{2}$ emissions in boreal aquatic ecosystems, Nat. Comm., 4, 2972, https://doi.org/10.1038/ncomms3972, 2013.

Larouche, J. R., Abbott, B. W., Bowden, W. B., and Jones, J. B.: The role of watershed characteristics, permafrost thaw, and wildfire on dissolved organic carbon biodegradability and water chemistry in Arctic headwater streams, Biogeosciences, 12, 42214233, https://doi.org/10.5194/bg-12-4221-2015, 2015.

Laurion, I. and Mladenov, N.: Dissolved organic matter photolysis in Canadian Arctic thaw ponds, Environ. Res. Lett., 8, 035026, doi.org/10.1088/1748-9326/8/3/035026, 2013.

Logue, J. B., Stedmon, C. A., Kellerman, A. M., Nielsen, N. J., Andersson, A. F., Laudon, H., Lindström, E. S., and Kritzberg, E. S.: Experimental insights into the importance of aquatic bacterial community composition to the degradation of dissolved organic matter, ISME J., 10, 533-545, 2016.

Lou, T. and Xie, H.: Photochemical alteration of the molecular weight of dissolved organic matter, Chemosphere, 65, 23332342, 2006.

MacIntyre, S., Cortes, A., and Sadro, S: Sediment respiration drives circulation and production of $\mathrm{CO}_{2}$ in ice-covered Alaskan arctic lakes, Limnol. Oceanogr. Lett., 3, 302-310, 2018.

Manasypov, R. M., Pokrovsky, O. S., Kirpotin, S. N., and Shirokova, L. S.: Thermokarst lake waters across the permafrost zones of western Siberia, The Cryosphere, 8, 1177-1193, https://doi.org/10.5194/tc-8-1177-2014, 2014.

Manasypov, R. M., Vorobyev, S. N., Loiko, S. V., Kritzkov, I. V., Shirokova, L. S., Shevchenko, V. P., Kirpotin, S. N., Kulizhsky, S. P., Kolesnichenko, L. G., Zemtzov, V. A., Sinkinov, V. V., and Pokrovsky, O. S.: Seasonal dynamics of organic carbon and metals in thermokarst lakes from the discontinuous permafrost zone of western Siberia, Biogeosciences, 12, 30093028, https://doi.org/10.5194/bg-12-3009-2015, 2015.

Mann, P. J., Davydova, A., Zimov, N., Spencer, R. G. M., Davydov, S., Bulygina, E., Zimov, S., and Holmes, R. M.: Controls on the composition and lability of dissolved organic matter in Siberia's Kolyma River basin, J. Geophys. Res., 117, G01028, https://doi.org/10.1029/2011JG001798, 2012.

Mann, P. J., Sobczak, W. V., LaRue, M. M., Bulygina, E., Davydova, A., Vonk, J. E., Schade, J., Davydov, S., Zimov, N., Holmes, R. M., and Spencer, R. G. M.: Evidence for key enzymatic controls on metabolism of Arctic river organic matter, Global Change Biol., 20, 1089-1100, 2014.

Mann, P. J., Eglinton, T. I., Mcintyre, C. P., Zimov, N., Davydova, A., Vonk, J. E., Holmes, R. M., and Spencer, R. G. M.: Utilization of ancient permafrost carbon in headwaters of Arctic fluvial networks, Nat. Commun., 6, 7856, https://doi.org/10.1038/ncomms8856, 2015.

Massicotte, P., Asmala, E., Stedmon, C., and Markager, S.: Global distribution of dissolved matter along the aquatic continuum: Across rivers, lakes and oceans, Sci. Total Environ., 609, 180191, 2017.

McCallister, S. L. and del Giorgio, P. A.: Direct measurement of the $\delta^{13} \mathrm{C}$ signature of carbon respired by bacteria in lakes: Linkages to potential carbon sources, ecosystem baseline metabolism, and $\mathrm{CO}_{2}$ fluxes, Limnol. Oceanogr., 53, 1204-1216, 2008.

Moody, C. S., Worrall, F., Evans, C. D., and Jones, T. G.: The rate of loss of dissolved organic carbon (DOC) through a catchment, J. Hydrol., 492, 139-150, 2013.

Moran, M. A., Sheldon, W. M., and Zepp, R. G.: Carbon loss and optical property changes during long-term photochemical and biological degradation of estuarine dissolved organic matter, Limnol. Oceanogr., 45, 1254-1264, 2000.

Mostofa, K. M. G., Yoshioka, T., Konohira, E., and Tanoue, E.: Photodegradation of fluorescent dissolved organic matter in river waters, Geochem. J., 41, 323-331, 2007.

Mostofa, K. M. G., Wu, F., Liu, C-Q., Vione, D., Yoshioka, T., Sakugawa, H., and Tanoue, E.: Photochemical, microbial and metal complexation behavior of fluorescent dissolved organic matter in the aquatic environments, Geochem. J., 45, 235-254, 2011.

Novikov, S. M., Moskvin, Y. P., Trofimov, S. A., Usova, L. I., Batuev, V. I., Tumanovskaya, S. M., Smirnova, V. P., Markov, M. L., Korotkevicth, A. E., and Potapova, T. M.: Hydrology of bog territories of the permafrost zone of western Siberia, BBM publ. House, St. Petersbourg, 535 pp., 2009 (in Russian).

Oleinikova, O., Drozdova, O. Y., Lapitskiy, S. A., Bychkov, A. Y., and Pokrovsky, O. S.: Dissolved organic matter degradation by sunlight coagulates organo-mineral colloids and produces lowmolecular weight fraction of metals in boreal humic waters, Geochim. Cosmochim. Ac., 211, 97-114, 2017.

Oleinikova, O., Shirokova, L. S., Drozdova, O. Y., Lapitsky, S. A., and Pokrovsky, O. S.: Low biodegradability of dissolved organic matter and trace metal from subarctic waters by culturable heterotrophic bacteria, Sci. Total Environ., 618, 174-187, 2018.

Page, S. E., Sander, M., Arnold, W. A., and McNeill, K.: Hydroxyl radical formation upon oxidation of reduced humic acids by oxygen in the dark, Environ. Sci. Technol., 46, 1590-1597, 2012.

Peacock, M., Evans, C. D., Fenner, N., Freeman, C., Gough, R., Jones, T. G., and Lebron, I.: UV-visible absorbance spectroscopy as a proxy for peatland dissolved organic carbon (DOC) quantity and quality: considerations on wavelength and absorbance degradation, Environ. Sci.: Processes Impacts, 16, 1445-1461, https://doi.org/10.1039/c4em00108g, 2014.

Pickard, A. E., Heal, K. V., McLeod, A. R., and Dinsmore, K. J.: Temporal changes in photoreactivity of dissolved organic carbon and implications for aquatic carbon fluxes from peatlands, Biogeosciences, 14, 1793-1809, https://doi.org/10.5194/bg-141793-2017, 2017.

Pokrovsky, O. S., Viers, J., Shirokova, L. S., Shevchenko, V. P., Filipov, A. S., and Dupré, B.: Dissolved, suspended, and colloidal 
fluxes of organic carbon, major and trace elements in Severnaya Dvina River and its tributary, Chem. Geol., 273, 136-149, 2010. Pokrovsky, O. S., Shirokova, L. S., Zabelina, S. A., Vorobieva, T. Ya., Moreva, O. Yu., Klimov, S. I., Chupakov, A. V., Shorina, N. V., Kokryatskaya, N. M., Audry, S., Viers, J., Zoutien, C., and Freydier, R.: Size fractionation of trace elements in a seasonally stratified boreal lakes: Control of organic matter and iron colloids, Aquat. Geochem., 18, 115-139, 2012.

Pokrovsky, O. S., Shirokova, L. S., Kirpotin, S. N., Kulizhsky, S. P., and Vorobiev, S. N.: Impact of western Siberia heat wave 2012 on greenhouse gases and trace metal concentration in thaw lakes of discontinuous permafrost zone, Biogeosciences, 10, 5349-5365, https://doi.org/10.5194/bg-10-5349-2013, 2013.

Pokrovsky, O. S., Manasypov, R. M., Loiko, S., Shirokova, L. S., Krickov, I. A., Pokrovsky, B. G., Kolesnichenko, L. G., Kopysov, S. G., Zemtzov, V. A., Kulizhsky, S. P., Vorobyev, S. N., and Kirpotin, S. N.: Permafrost coverage, watershed area and season control of dissolved carbon and major elements in western Siberian rivers, Biogeosciences, 12, 63016320, https://doi.org/10.5194/bg-12-6301-2015, 2015.

Pokrovsky, O. S., Manasypov, R. M., Loiko, S. V., and Shirokova, L. S.: Organic and organo-mineral colloids of discontinuous permafrost zone, Geochim. Cosmochim. Ac., 188, 1-20, 2016.

Porcal, P., Dillon, P. J., and Molot, L. A.: Photochemical production and decomposition of particulate organic carbon in a freshwater stream, Aquat. Sci., 75, 469-482, 2013.

Porcal, P., Dillon, P. J., and Molot, L. A.: Interaction of extrinsic chemical factors affecting photodegradation of dissolved organic matter in aquatic ecosystems, Photochem. Photobio. S., 13, 799812,2014

Porcal, P., Dillon, P. J., and Molot, L. A.: Temperature dependence of photodegradation of dissolved organic matter to dissolved inorganic carbon and particulate organic carbon, Plos ONE, 10, e0128884, https://doi.org/10.1371/journal.pone.0128884, 2015.

Porter, K. G. and Feig, Y. S.: The use of DAPI for identifying and counting aquatic microflora, Limnol. Oceanogr., 25, 943-948, 1980.

Raudina, T. V., Loiko, S. V., Lim, A., Manasypov, R. M., Shirokova, L. S., Istigecgev, G. I., Kuzmina, D. M., Kulizhsky, S. P., Vorobyev, S. N., and Pokrovsky, O. S.: Permafrost thaw and climate warming may decrease the $\mathrm{CO}_{2}$, carbon, and metal concentration in peat soil waters of the Western Siberia Lowland, Sci. Total Environ., 634, 1004-1023, 2018.

Reader, H. E., Stedmon, C. A., and Kritzberg, E. S.: Seasonal contribution of terrestrial organic matter and biological oxygen demand to the Baltic Sea from three contrasting river catchments, Biogeosciences, 11, 3409-3419, https://doi.org/10.5194/bg-113409-2014, 2014.

Reche, I., Pace, M. L., and Cole, J. J.: Modeled effects of dissolved organic carbon and solar spectra on photobleaching in lake ecosystems, Ecosystems 3, 419-432, 2000.

Roehm, C. L., Giesler, R., and Karlsson, J.: Bioavailability of terrestrial organic carbon to lake bacteria: The case of a degrading subarctic permafrost mire complex, J. Geophys. Res., 114, G03006, https://doi.org/10.1029/2008JG000863, 2009.

Selvam, B. P., Lapierre, J.-F., Guillemette, F., Voigt, C., Lamprecht, R. E., Biasi, C., Christensen, T. R., Martikainen P. J., and Berggren, M.: Degradation potentials of dissolved organic carbon (DOC) from thawed permafrost peat, Sci. Rep.-UK, 7, 45811, https://doi.org/10.1038/srep45811, 2017.

Serikova, S., Pokrovsky, O. S., Ala-aho, P., Kazantsev, V., Kirpotin, S. N. Kopysov, S. G., Krickov, I. V., Laudon, H., Manasypov, R. M., Shirokova, L. S., Sousby, C., Tetzlaff, D., and Karlsson, J.: High riverine $\mathrm{CO}_{2}$ emissions at the permafrost boundary of Western Siberia, Nat. Geosci., 11, 825-829, 2018.

Serikova S., Pokrovsky O. S., Laudon, H., Krickov, I. V., Lim, A. G., Manasypov, R. M., and Karlsson, J.: C emissions from lakes across permafrost gradient of Western Siberia, Nat. Commun. 10, 1552, https://doi.org/10.1038/s41467-019-09592-1, 2019.

Shirokova, L. S., Pokrovsky, O. S., Moreva, O. Y., Chupakov, A. V., Zabelina, S. A., Klimov, S. I., Shorina, N. V., and Vorobieva T. Y.: Decrease of concentration and colloidal fraction of organic carbon and trace elements in response to the anomalously hot summer 2010 in a humic boreal lake, Sci. Total Environ., 463464, 78-90, 2013a.

Shirokova, L. S., Pokrovsky, O. S., Kirpotin, S. N., Desmukh, C., Pokrovsky, B. G., Audry, S., and Viers, J.: Biogeochemistry of organic carbon, $\mathrm{CO}_{2}, \mathrm{CH}_{4}$, and trace elements in thermokarst water bodies in discontinuous permafrost zones of Western Siberia, Biogeochemistry, 113, 573-593, 2013b.

Shirokova, L. S., Bredoire, R., Rolls, J. L., and Pokrovsky, O. S.: Moss and peat leachate degradability by heterotrophic bacteria: fate of organic carbon and trace metals, Geomicrobiol. J., 34, 641-655, 2017a.

Shirokova, L. S., Chupakova, A. A., Chupakov, A. V., and Pokrovsky, O. S.: Transformation of dissolved organic matter and related trace elements in the mouth zone of the largest European Arctic river: experimental modeling, Inland Waters, 7, 272 282, 2017b.

Spencer, R. G. M., Stubbins, A., Hernes, P. J., Baker, A., Mopper, K., Aufdenkampe, A. K., Dyda, R. Y., Mwamba, V. L., Mangangu, A. M., Wabakanghanzi, J. N., and Six, J.: Photochemical degradation of dissolved organic matter and dissolved lignin phenols from the Congo River, J. Geophys. Res., 114, G03010, https://doi.org/10.1029/2009JG000968, 2009.

Spencer, R. G. M., Mann, P. J., Dittmar, T., Eglinton, T. I., McIntyre, C., Holmes, R. M., Zimov, N., and Stubbins, A.: Detecting the signature of permafrost thaw in Arctic rivers, Geophys. Res. Lett., 42, 2830-2835, 2015.

Stubbins, A., Mann, P. J., Powers, L., Bittar, T. B., Dittmar, T., McIntyre, C. P., Eglinton, T. I., Zimov, N., and Spencer, R. G. M.: Low photolability of yedoma permafrost dissolved organic carbon, J. Geophys. Res.-Biogeo., 122, 200-211, https://doi.org/10.1002/2016JG003688, 2017.

Stutter, M. I., Richards, S., and Dawson, J. J. C.: Biodegradability of natural dissolved organic matter collected from a UK moorland stream, Water Res., 47, 1169-1180, 2013.

Sulzberger, B., Austin, A. T., Cory, R. M., Zepp, R. G., and Paul, N. D.: Solar UV radiation in a changing world: roles of cryosphere-land-water-atmosphere interfaces in global biogeochemical cycles, Photochem. Photobio. S., 18, 747-774, https://doi.org/10.1039/c8pp90063a, 2019.

Tarnocai, C., Canadell, J. G., E. Schuur A. G., Kuhry P., Mazhitova G., and Zimov S.: Soil organic carbon pools in the northern circumpolar permafrost region, Global Biogeochem. Cy., 23, GB2023, https://doi.org/10.1029/2008GB003327, 2009. 
Textor, S. R., Guillemette, F., Zito, P. A., and Spencer, R. G. M.: An assessment of dissolved organic carbon biodegradability and priming in blackwater systems, J. Geophys. Res.-Biogeo., 123, 2998-3015, 2018.

Uyguner, C. and Bekbolet, M.: Implementation of spectroscopic parameters for practical monitoring of natural organic matter, Desalination, 176, 47-55, 2005.

Valle, J., Gonsior, M., Hairir, M., Enrich-Prast, A., SchmittKopplin, P., Bastviken, D., Conrad R., and Hertkorn, N.: Extensive processing of sediment pore water dissolved organic matter during anoxic incubation as observed by high-field mass spectrometry (FTICR-MS), Water Res., 129, 252-263, 2018.

Vähätalo, A. V. and Wetzel, R. G.: Photochemical and microbial decomposition of chromophoric dissolved organic matter during long (months-years) exposures, Mar. Chem., 89, 313-326, 2004.

Vähätalo, A. V., Salonen, K., Münster, U., Järvinen, M., and Wetzel, R. G.: Photochemical transformation of allochthonous organic matter provides bioavailable nutrients in a humic lake, Acta Hydrobiol., 156, 287-314, 2003.

Vasyukova, E., Pokrovsky, O. S., Viers, J., Oliva, P., Dupré, B., Martin, F., and Candaudap, F.: Trace elements in organic- and ironrich surficial fluids of boreal zone: Assessing colloidal forms via dialysis and ultrafiltration, Geochim. Cosmochim. Ac., 74, 449468, 2010.

Vonk, J. E., Tank, S. E., Mann, P. J., Spencer, R. G. M., Treat, C. C., Striegl, R. G., Abbott, B. W., and Wickland, K. P.: Biodegradability of dissolved organic carbon in permafrost soils and aquatic systems: a meta-analysis, Biogeosciences, 12, 69156930, https://doi.org/10.5194/bg-12-6915-2015, 2015.

Vorobyev, S. N., Pokrovsky O. S., Kolesnichenko, L. G., Manasypov, R. M., Shirokova, L. S., Karlsson, J., and Kirpotin, S. N.: Biogeochemistry of dissolved carbon, major and trace elements during spring flood periods on the Ob River, Hydrol. Process., 33, 1579-1594, 2019.
Ward, C. P. and Cory, R. M.: Complete and partial photo-oxidation of dissolved organic matter draining permafrost soils, Environ. Sci. Technol., 50, 3545-3553, 2016.

Ward, C. P., Nalven, S. G., Crump, B. C., Kling, G. W., and Cory, R. M.: Photochemical alteration of organic carbon draining permafrost soils shifts microbial metabolic pathways and stimulates respiration, Nat. Commun., 8, 772, https://doi.org/10.1038/s41467-017-00759-2, 2017.

Wauthy M., Rautio, M., Christoffersen, K. S., Forsstrom, L., Laurion, I., Mariash, H. L., Peura, S., and Vincent, W. F.: Increasing dominance of terrigenous organic mtter in circumpolar freshwaters due to permafrost thaw, Limnol. Oceanogr. Lett., 3, 186-198, 2018.

Weishaar, J. L., Aiken, G. R., Bergamaschi, B. A., Fram, M. S., Fujii, R., and Mopper, K.: Evaluation of specific ultraviolet absorbance as an indicator of the chemical composition and reactivity of dissolved organic carbon, Environ. Sci. Technol., 37, 47024708, 2003.

Wickland, K. P., Aiken, G. R., Butler, K., Dornblaser, M. M., Spencer, R. G. M., and Striegl, R. G.: Biodegradability of dissolved organic carbon in the Yukon River and its tributaries: seasonality and importance of inorganic nitrogen. Global Biogeochem. Cy., 26, GB0E03, https://doi.org/10.1029/2012GB004342, 2012.

Wilkinson, G. M., Pace, M. L., and Cole, J. J.: Terrestrial dominance of organic matter in north temperate lakes, Global. Biogeochem. Cy., 27, 43-51, 2013.

Winter, A. R., Fish, T. A. E., Playle, R. C., Smith, D. S., and Curtis, P. J.: Photodegradation of natural organic matter from diverse freshwater sources, Aquat. Toxicol., 84, 215-222, 2007. 